Article

\title{
Geochemical Alteration and Mineralogy of Coals under the Influence of Fault Motion: A Case Study of Qi'nan Colliery, China
}

\author{
Hewu Liu ${ }^{1,2}$ and Bo Jiang ${ }^{1,2, *(1)}$ \\ 1 Key Laboratory of Coalbed Methane Resource \& Reservoir Formation Process, Ministry of Education, China \\ University of Mining and Technology, Xuzhou 221008, China \\ 2 School of Resources and Earth Science, China University of Mining and Technology, Xuzhou 221116, China \\ * Correspondence: jiangbo@cumt.edu.cn
}

Received: 30 April 2019; Accepted: 25 June 2019; Published: 27 June 2019

check for updates

\begin{abstract}
Geochemical characteristics of rocks in fault zones have been extensively studied, while there are limited studies on coal occurring in fault zones of underground coal mine. In this study, five coal samples were carefully collected from a reverse fault zone in Qi'nan colliery. Systematical detection methods were employed to analyze the different chemical and physical characteristics of fault-related coal samples. Through comparative analysis, the following insights are obtained. Three subdivided fault zones were classified according to the deformation characteristics of coal samples. Frictional heat and strong ductile deformation generated by fault motion led to the dissociation of phenol and carboxyl groups in coal molecules, which sharply decreased the concentrations of elements $\mathrm{Co}$ and Mo bound to these functional groups in zone I. The modified pore-cleat system in zone I with higher pore volume and lower permeability allowed solutions containing enriched trace elements to migrate through zone I locally. Concentrations of HREE, MREE and related elements associated with the invasive solutions showed significant positive anomalies in zone I. Precipitation and smearing of clay minerals in zone I led to poorer connectivity. Disruption and delamination of laminar clay minerals by strong compression-shear stress significantly increased the adsorption sites for related elements, especially the HREE and MREE. Nano-scale clay minerals resulting from stress-induced scaly exfoliation also enhanced the retention capability of REE in zone I.
\end{abstract}

Keywords: minerals; trace elements; major elements; fault zone; tectonically deformed coal; differentiation mechanism

\section{Introduction}

Geochemical and geophysical characteristics of fault rocks are primarily controlled by fault zones or fault systems [1-5]. Fault zones in rocks are generally divided into fault core (comprised of ultracataclasite), damage zone and undeformed zone (comprised of protolith) [6,7]. Geochemical properties of fault rocks are altered in different ways. During faulting deformation, faults acting as major conduits for fluid migration lead to strong fluid-rock interactions [8]. Fluid-rock interactions in fault zones not only heal macro and micro fracture networks, but also lead to elemental variation and weathering of the fault core $[9,10]$. Most of the elements in fault core are depleted compared with those in the damage zone, which is ascribed to a stronger weathering process in the fault core [11]. Redistribution of elements and minerals in different subdivided zones could also result from the pressure solution of soluble minerals and diffusive mass transfer [12-14]. The formation of clay minerals in fault gouge is closely associated with the dehydration process and fluid-rock interactions in fault zones [9]. 
The permeability of fault rocks is both temporally and spatially heterogeneous. The permeability controls the migration of fluid in different subdivided zones, which is important for the chemical alteration of fault rocks [15-17]. A cyclic permeability evolution of fault zones occurs during the process of faulting deformation [8]. During faulting deformation, fractures and cataclasis within the fault core significantly increase the permeability of rocks, which is beneficial to the fluid migration [18,19]. After faulting deformation, the fault core sealed by mineral cementation and diffusive mass transfer has lower permeability [20-23]. Strong shear stress on fault planes leads to smearing of clay minerals into thin films (even nano-sized clay films), which decreases the permeability of fault-related coal as well $[24,25]$. As a summary, permeability evolution, fluid migration, and chemical alteration in fault zones are auxiliary to each other in a faulting deformation process.

Similarly, faults in coal seams are related to tectonic stress concentration, which could strongly alter intact coals into deformed ones [26]. In other words, fault structures control the local distribution of tectonically deformed coals (TDCs). TDCs are defined as coals superimposed by tectonic stress [27]. The chemical structure (specifically referring to the organic structure), physical structure and optical characteristics of TDCs are significantly affected by tectonic deformation [27-29]. Strong deformation (especially ductile deformation) on coal significantly increases the total volume and specific surface area of pore structures [30-36]. Moreover, it has been reported that there is early metamorphism of coal molecular structures in TDCs $[37,38]$. Side chains in TDCs including aliphatic structures and functional groups are disassociated by tectonic stress, which is followed by aromatic structures being collaged and rearranged (especially in ductile deformed coal) [39,40]. Furthermore, relevant studies have shown that coal molecular structures around faults are altered by strong deformation and frictional heat [41-43]. On the other hand, insufficient attention has been paid to the alteration of inorganic components in TDCs, particularly in fault-related coals. Thus, a study on deformed coal around fault structures could further advance the understanding of accumulation and dissipation mechanisms of elements under the influence of tectonic structures.

Elements in coal have long been investigated by geologists for preserved geological information, release of toxic elements during utilization process, and the potential economic significance of specific valuable elements [44-49]. The distribution of elements and minerals in coal seams is influenced by both syngenetic and epigenetic geological factors, for instance, the syngenetic inputs of terrigenous debris, mesotrophic anoxic conditions, volcanic ashes etc., and the epigenetic factors of igneous intrusion, circulating ground water etc. $[47,50-56]$. However, only few researchers have recognized that the characteristics of inorganic components in TDCs are influenced by tectonic stress as well. Actually, inorganic components in coal are closely associated with tectonic deformation [36,57-61]. For instance, fluids migrating through brecciated coals in fault zones probably lead to cleat mineralization and elemental enrichment $[58,59,61]$. Specifically, the concentrations of Ti, Sc, Ta, U and rare earth elements all increase as the coal deformation increases, while the concentration of Mo decreases with increasing deformation intensity, which can be mainly ascribed to the coal dynamic metamorphism accompanied by frictional thermal effects [62-65]. Analogously, concentrations of rare earth elements in fault-related boreholes are higher than those in unrelated boreholes in specific coal seams. Thus, it has been proposed that fault structures are beneficial to the accumulation of rare earth elements [66]. Therefore, the investigation of the geochemical alteration characteristics and mechanisms of deformed coals provides another perspective to understand the coal deformation mechanisms [62]. More importantly, coal and gas outbursts are considered to be closely related to strongly deformed coal, which is unpredictable during coal production [38]. Once the elemental variation characteristics and mechanisms in deformed coals are clarified, concentrations of elements could be applied as precise indicators of coal and gas outbursts [62,65,67].

In this study, a series of deformed coal samples located at different distances from a reverse fault are systematically studied from diverse perspectives. Based on the knowledge of geochemical characteristics of fault-related coal samples, differentiation mechanisms of trace elements in the fault zone are preliminarily clarified. 


\section{Geological Settings and Fault Zone Architecture}

\subsection{Geological Settings}

Suxian coal mine, adjacent to Tanlu fault, is on the southeastern margin of the Northern China plate (Figure 1a). Multiple tectonic movements occurring in Suxian coal mine significantly altered the regional and primary structural features of coal deposited in this area. In the late Triassic (Indo-Chinese epoch), the collage and collision between Yangtze craton and North China craton led to the NS extrusion of Suxian coal mine, which induced the emergence of EW-trending folds and faults in the study area. The Yanshanian-Himalayan tectonic movement in early-middle Jurassic directly resulted in the formation of East Suzhou syncline, South Suzhou syncline and Xisipo thrust fault [27], which dominated the geological structure frame of Suxian coal mine (Figure 1b). South Suzhou syncline, with an axial direction of NE-20 $0^{\circ}$, was cut into a half-baked syncline structure by Xisipo thrust fault. Under the influence of the cutting, the dip angle of east flank (about $45^{\circ}$ ) of South Suzhou syncline is greater than that of the west flank (about $25^{\circ}$ ). The main structural trace of Suxian coal mine is basically in the NNE direction (Figure 1b).

Qi'nan colliery, the selected sampling area, is at the turn end of South Suzhou syncline. Faults are the predominant structures that control the local distribution of TDCs in Qi'nan colliery. Two secondary folds, nearly along the EW direction, are develop in the central part of Qi'nan colliery. Samples were collected from a reverse fault that was adjacent to the axis of the Zhangxuewu syncline (Figure 1c). The EW-trending reverse fault was formed under the squeezing of tectonic stress in a NS direction originating from the Indo-China movement. This reverse fault was less affected by Yanshanian-Himalayan tectonic movement.

Furthermore, Yanshanian igneous intrusion in Huaibei coalfield belongs to the circum-Pacific tectonic magmatic belt. The Xierpu igneous rocks located in the northwest of Suzhou city were intruded up to the shallow part of through north Suzhou fault (Figure 1b). Faults developed in Zhuxianzhuang colliery are important magma transportation channels. Coal seam VI was influenced by the igneous intrusion as well (Figure 1d).

Shanxi Formation of lower Permian and lower Shihezi Formation of middle Permian are major coal-bearing strata in Qi'nan colliery (Figure 1d). Fault-related coal samples were collected in coal seam VI, lower Shihezi formation. The lower Shihezi formation, as a fluvial-dominated delta plain deposit, is mainly comprised of sandstone, mudstone and coal, which is conformable with the underlying Shanxi Formation and distributed regionally. The direct roof and floor of coal seam VI are mainly mudstone.

The hydrogeological resources of Qi'nan colliery are mainly the fourth aquifer in Cenozoic and the sandstone fissured aquifer of coal-bearing strata in Permian. The decreasing water level of the fourth aquifer after coal mining indicates that the source of water in coal is mainly the fourth aquifer. The sandstone-fissured aquifer could directly enter the coal seam through leaching and could be recharged by the fourth aquifer. The $\mathrm{pH}$ value of ground water penetrating into coal seams from an overlying aquifer is in the range of 7.2-7.9, which makes coal seam VI mildly alkaline as well [68].

\subsection{Fault Zone Architecture}

The dip direction and dip angle of the selected reverse fault are $358^{\circ}$ and $35^{\circ}$, respectively (Figure 2). The direct roof and floor of coal seam VI are mainly grey mudstone, and the thick false roof and floor are mainly grey green mudstone. Roof and floor rocks dislocated by the fault are broken into cataclastic shapes near the fault plane followed by intact roof and floor rocks away from the fault plane. Field observation showed that there were dragged folds developing in hanging and foot walls near the fault plane (Figure 2). Coal, being more sensitive to tectonic stress, was broken into strongly deformed structures in dragged fold zones (zone I) with widths of $\sim 2$ meters in both hanging and foot walls. The influence of the fault on coal deformation became weak in the part with normal occurring roof and floor rocks. At a distance of $\sim 4$ meters from zone I in both hanging and foot walls, dense associated fractures cut most coal into mortar shapes (zone II). Coal beyond zone II showed relatively intact 
shapes (zone III). Besides, field observation showed that subdivided zones in the hanging wall were slightly broader than those in the footwall.

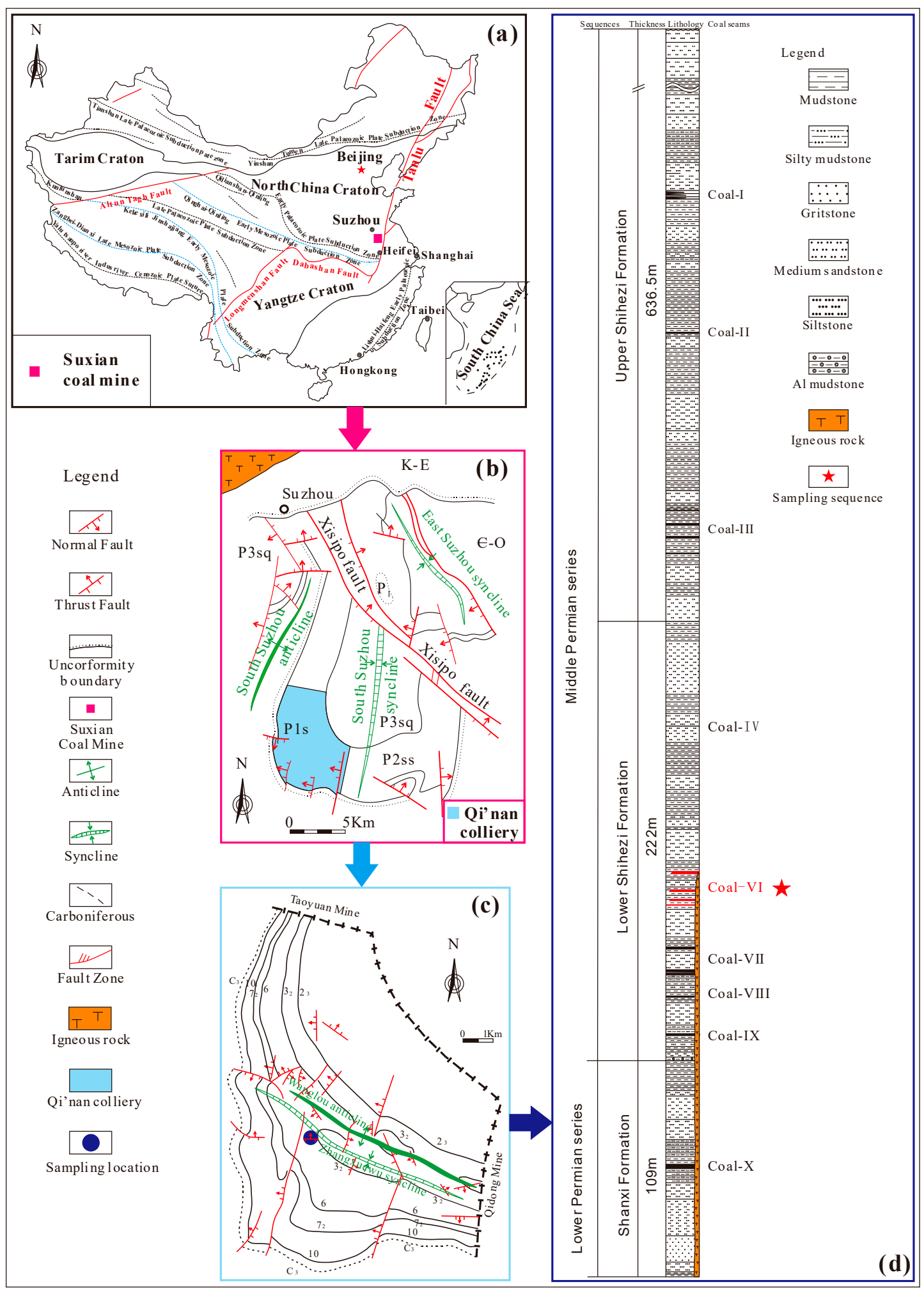

Figure 1. The location of sampling sites and sequence. (a) Map of China. (b) Structural outline of Suxian coal mine. (c) Structural outline of Qi'nan colliery and distribution of sampling location (modified from Jiang et al. [27]; Li et al. [69]). (d) Detailed stratigraphic column of coal-bearing strata in Qi'nan colliery. 


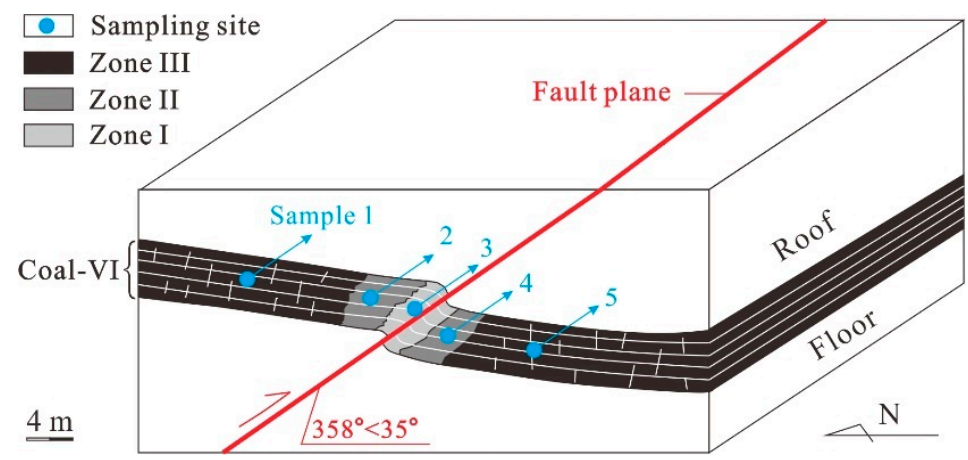

Figure 2. Schematic of fault zone architecture and distribution of sampling sites.

According to the guidelines of GB482-1995 Standard [70], five TDC samples with typical deformation characteristics in three subdivided zones were collected from the same sequence. Among them, samples 1, 2 and 3 were collected from the hanging wall, and samples 4 and 5 were collected from the foot wall. Samples 1 and 5 were collected in zone III; samples 2 and 4 were gathered in zone II; and sample 3 was collected in zone I (Figure 2).

Samples in zone III: Samples 1 and 5 in zone III are defined as cataclastic coal (Figure 3a,e). Maceral bands in these samples are clearly visible. Coal body with more integrated structures are mainly cut by straight and sparse cleats with flat surfaces.
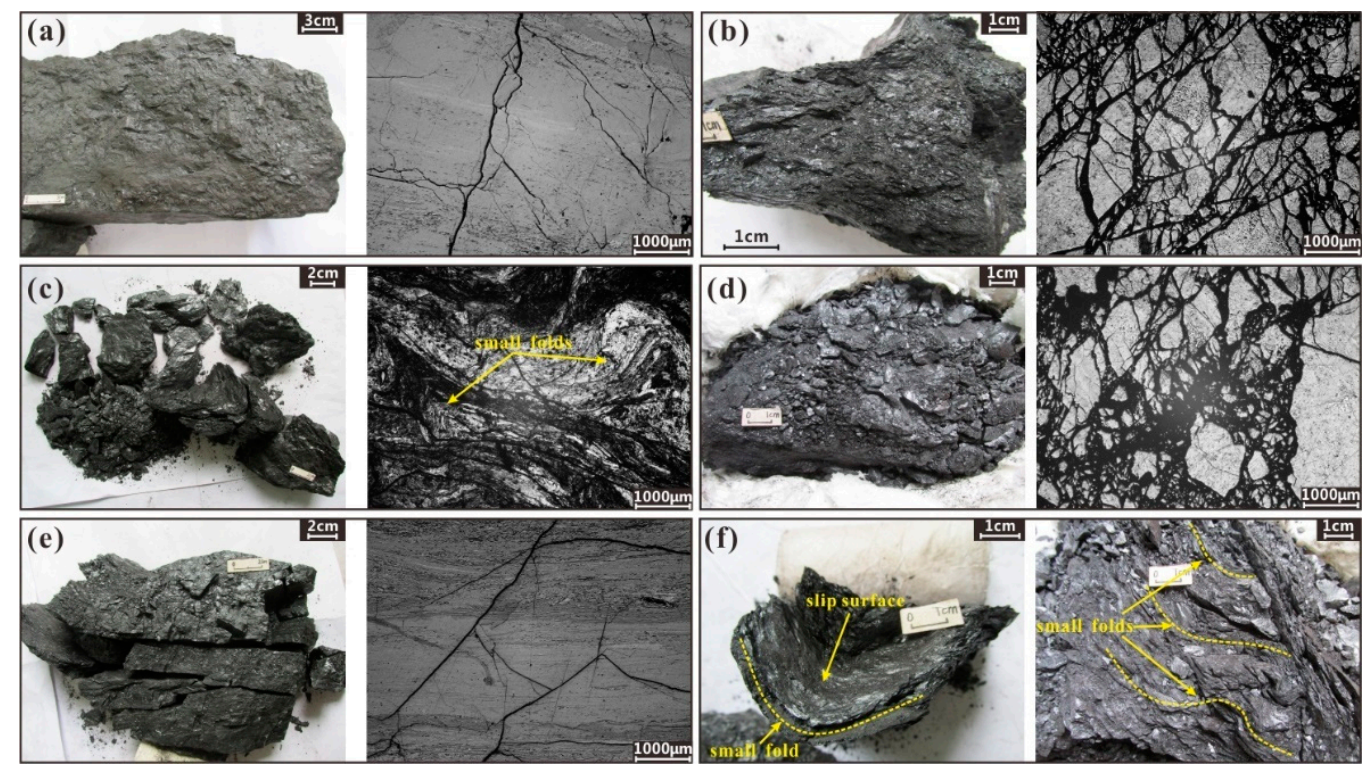

Figure 3. The macro and micro deformation characteristics of fault-related coal samples; (a-e) are images of micro and macro deformation characteristics of samples 1-5 sequentially (left images show macro deformation characteristics, right images show micro deformation characteristics). (f) Small folds and slip surface developed in sample 3.

Samples in zone II: Samples 2 and 4 in zone II are defined as mortar coal (Figure 3b,d). These samples are smashed into pieces by compression stress, and they show lower mechanical strength to the samples in zone III. The cleats developed in these two samples are denser compared with those of samples 1 and 5 . Shapes of coal particles are angular or sub-angular.

Sample in zone I: Sample 3 is defined as wrinkle coal (Figure 3c). Coal developed in zone I is formed in a strong compression-shear stress environment. Sample 3 could easily be crumpled by hand into powder or grains. Small micro "folds" are well developed in zone I, indicating a strong ductile deformation (Figure 3c,f). Squeezing and slippage of the coal matrix led to the development of frictional mirror surfaces (Figure 3f). 


\section{Experiments}

Bulk fault-related coal samples were firstly consolidated by injecting epoxy. Then, consolidated samples were polished perpendicular to marcel bands by using the sandpapers and $\mathrm{Al}_{2} \mathrm{O}_{3}$ colloidal solution. The micro deformation characteristics were observed through polished faces by using Polarizing Microscope Eclipse LV100N Pol (Nikon, Tokyo, Japan) in a reflected light. The polarizing microscope is equipped with illumination lamphouse (LV-LH50PC, Nikon, Tokyo, Japan).

Ultimate analysis of the samples was performed using Vario Macro Cube element analyzer (manufactured by Elementar, Hanau, Germany). Specifically, the detection of total sulfur contents was based on ASTM standard D3177-02 (2002). The proximate analysis of fault-related coal samples was in accordance with the ASTM Standards including ASTM D3174-12 (2012), ASTM D3175-17 (2017), ASTM D3173/D3173M-17a (2017), and ASTM D3175-17 (2017). Both ultimate analysis and proximate analysis were performed in Xuzhou Inspection Center of China National Administration of Coal Geology.

Concentrations of trace elements in various TDCs were analyzed by using inductively coupled plasma mass spectrometry (ICP-MS, Agilent, Santa Clara, CA, USA) following a two-step digestion method. Firstly, dry powder samples (200 mesh) were ashed $\left(500{ }^{\circ} \mathrm{C}\right)$ in a muffle furnace for $4 \mathrm{~h}$. Then, the ash samples were extracted with $\mathrm{HNO}_{3}$, and the residue was dissolved by a mixture of $\mathrm{HF}: \mathrm{HNO}_{3}: \mathrm{HClO}_{4}$ subsequently in a closed microwave digestion system with high pressure. Concentrations of trace elements in standard reference materials (SARM-19) and blank samples were also determined to calibrate the detection results. Concentrations of major element oxides in the high-temperature $\left(815^{\circ} \mathrm{C}\right)$ ash were determined by means of X-ray fluorescence spectrometry (XRF, Bruker, Karlsruhe, Germany) in the Advanced Analysis and Computation Center of China University of Mining and Technology.

Morphological characteristics of minerals in selected bulk TDC samples were observed by the FEI Quanta TM 250 scanning electron microscope equipped with an energy dispersive X-ray analyzer (SEM-EDX, FEI, Hillsboro, OR, USA) in the Advanced Analysis and Computation Center of China University of Mining and Technology. X-ray diffraction (XRD, Bruker, Karlsruhe, Germany) spectra for fault-related coal samples were acquired using Bruker D8 Advance instrument (Cu target, K $\alpha$ radiation) equipped with $0.6-\mathrm{mm}$ divergence slit and 8-mm anti-scatter slit systems. Operating conditions of the X-ray tube were $\mathrm{U}=40 \mathrm{kV}$ and $\mathrm{I}=30 \mathrm{~mA}$.

Characteristics of hydroxyl groups in organic and inorganic compounds of coal were analyzed by using Fourier transform infrared spectroscopy (FT-IR, Bruker, Karlsruhe, Germany). Powdered whole coal samples $(0.9 \mathrm{mg}$, higher than 200 mesh) were initially ground with $80 \mathrm{mg}$ of potassium bromide (KBr) for $20 \mathrm{~min}$ in an agate mortar. The powder mixture was pressed into a transparent disc for 10 min using a tablet machine. Pure ground KBr was used to obtain a reference spectrum. The discs were analyzed by VERTEX-70 FT-IR (Bruker, Germany), and the spectra were recorded in the range of 400 to $4000 \mathrm{~cm}^{-1}$ with a resolution of $4 \mathrm{~cm}^{-1}$.

Characteristics of a pore-cleat system of fault-related coals were detected by using Macromerities 9500-type mercury porosimetry (Micromeritics, Drive Norcross, GA, USA) with a pore diameter ranging from $3 \mathrm{~nm}$ to $0.23 \mathrm{~mm}$ and pressure up to $413 \mathrm{MPa}$ at the Key Laboratory of Coalbed Methane Resources and Reservoir Formation Process, China Ministry of Education. Pores with diverse pore sizes from millimeters to nanometers could be measured by this method [71].

\section{Results}

\subsection{Coal Chemistry}

As shown in Table 1, the fixed carbon $\left(\mathrm{FC}_{\mathrm{d}}\right)$ values of the five samples were in the range of $51.81-55.78 \%$ and the volatile matter $\left(\mathrm{V}_{\mathrm{daf}}\right)$ ranged from $34.27 \%$ to $35.88 \%$, indicating high volatile bituminous coals according to the ASTM D388-18 standard. Samples with total sulfur content lower than $1 \%$ were classified as low grade based on the GB/T standard 15224.2-2004. The ash yields of samples 2 and 3 were slightly higher than others. Furthermore, the $R_{\mathrm{o}, \max }$ of sample 3 was a little 
higher than the other samples, indicating that sample 3 was of higher maturation degree (Table 1). The early-coalification phenomenon that occurred in sample 3 was mainly attributed to the dynamic metamorphism of intensive tectonic deformation [40-42].

Table 1. Proximate and ultimate analyses of fault-related coal samples.

\begin{tabular}{|c|c|c|c|c|c|c|c|c|c|c|c|}
\hline \multirow{2}{*}{$\begin{array}{c}\text { Coal } \\
\text { Samples }\end{array}$} & \multirow{2}{*}{$\underset{(\%)}{R_{0, \max }}$} & \multicolumn{5}{|c|}{ Proximate Analysis } & \multicolumn{5}{|c|}{ Ultimate Analysis } \\
\hline & & $\mathbf{M}_{\mathrm{ad}}$ & $\mathbf{A}_{\mathrm{d}}$ & $\mathbf{V}_{\text {daf }}$ & $\begin{array}{l}\text { Coking } \\
\text { Index }\end{array}$ & $\mathrm{FC}_{\mathrm{d}}$ & $\mathrm{S}_{\mathrm{t} . \mathrm{d}}$ & $\mathrm{O}_{\mathrm{daf}}$ & $\mathrm{C}_{\mathrm{daf}}$ & $\mathbf{H}_{\text {daf }}$ & $\mathbf{N}_{\text {daf }}$ \\
\hline 1 & 0.90 & 1.04 & 16.95 & 35.00 & 6 & 52.88 & 0.12 & 8.79 & 84.35 & 5.43 & 1.28 \\
\hline 2 & 0.89 & 1.41 & 19.21 & 34.27 & 6 & 52.30 & 0.18 & 9.55 & 83.42 & 5.30 & 1.50 \\
\hline 3 & 0.91 & 1.45 & 18.52 & 35.88 & 6 & 51.31 & 0.19 & 9.86 & 83.83 & 4.68 & 1.39 \\
\hline 4 & 0.92 & 1.21 & 17.10 & 34.93 & 6 & 51.81 & 0.17 & 10.90 & 82.57 & 4.98 & 1.32 \\
\hline 5 & 0.88 & 1.20 & 12.18 & 35.71 & 6 & 55.78 & 0.20 & 8.43 & 84.84 & 5.02 & 1.48 \\
\hline
\end{tabular}

Note: $R_{\mathrm{o}, \max }$ : Maximum reflectance of vitrinite; $\mathrm{M}_{\mathrm{ad}}$ : Inherent moisture content with air-dried basis; $\mathrm{A}_{\mathrm{d}}$ : Ash yield with dry basis; $V_{\text {daf }}$ : Volatile matter yield with dry-ash-free basis; $F_{d}$ : Fixed carbon content with dry basis; ad: Air-dried basis; d: dry basis; daf: Dry-ash-free basis.

\subsection{Minerals in the Reverse Fault Zone}

XRD results showed that the minerals of five coal samples were mainly composed of clay minerals, carbonates and quartz (Figure 4). Clay minerals occupying the first place in samples mainly consisted of nacrite, kaolinite and dickite; and carbonates in the second place were mainly composed of calcite and dolomite. Compared with samples 2-4, quartz and carbonate were more developed in samples 1 and 5 respectively, while dickite could only be found in sample 3. Additionally, SEM-EDX results showed that sulfide and sulfate minerals could also be found in fault-related samples, for example, pyrite and sulphate.

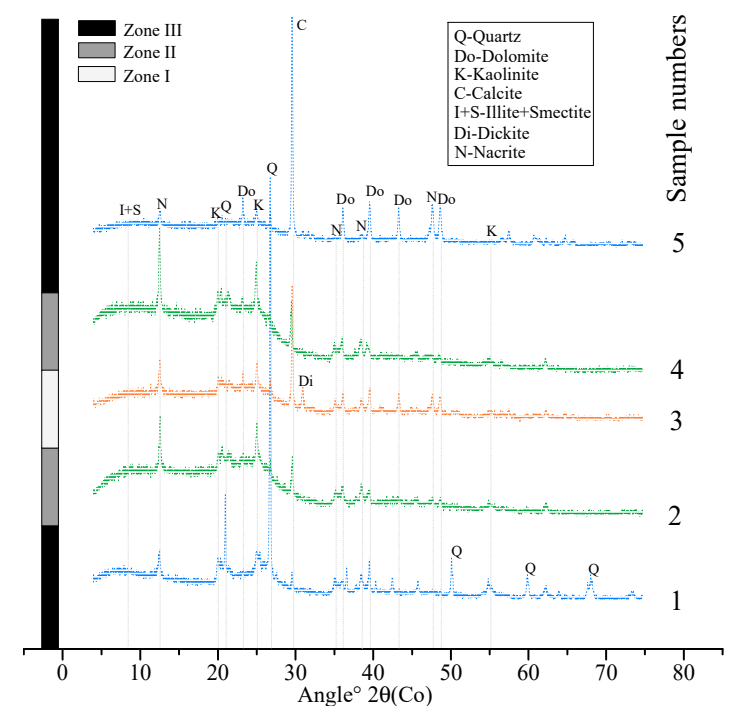

Figure 4. The XRD spectrums of fault-related coal samples.

In sample 3, clay minerals commonly precipitated in pore or cleat structures (Figure 6a-f). While for other samples, clay minerals usually occur as syngenetic precipitates in the cell of fusinite (Figure 5a,b). With a close distance to the fault structure, clay minerals filled in cells were obviously squeezed with the structural failure of fusinite. Besides, calcite and dolomite in the samples always occurred as cleat fillings (Figure 6g,i). Furthermore, pyrite in sample 3 was observed as cleat infillings, indicating the post-depositional mineralization process [72]. However, pyrite in other samples commonly occurred as syngenetic lumps or cell infillings. Therefore, different occurrence modes of minerals indicated that sample 3 was significantly affected by epigenetic factors compared with other samples. 


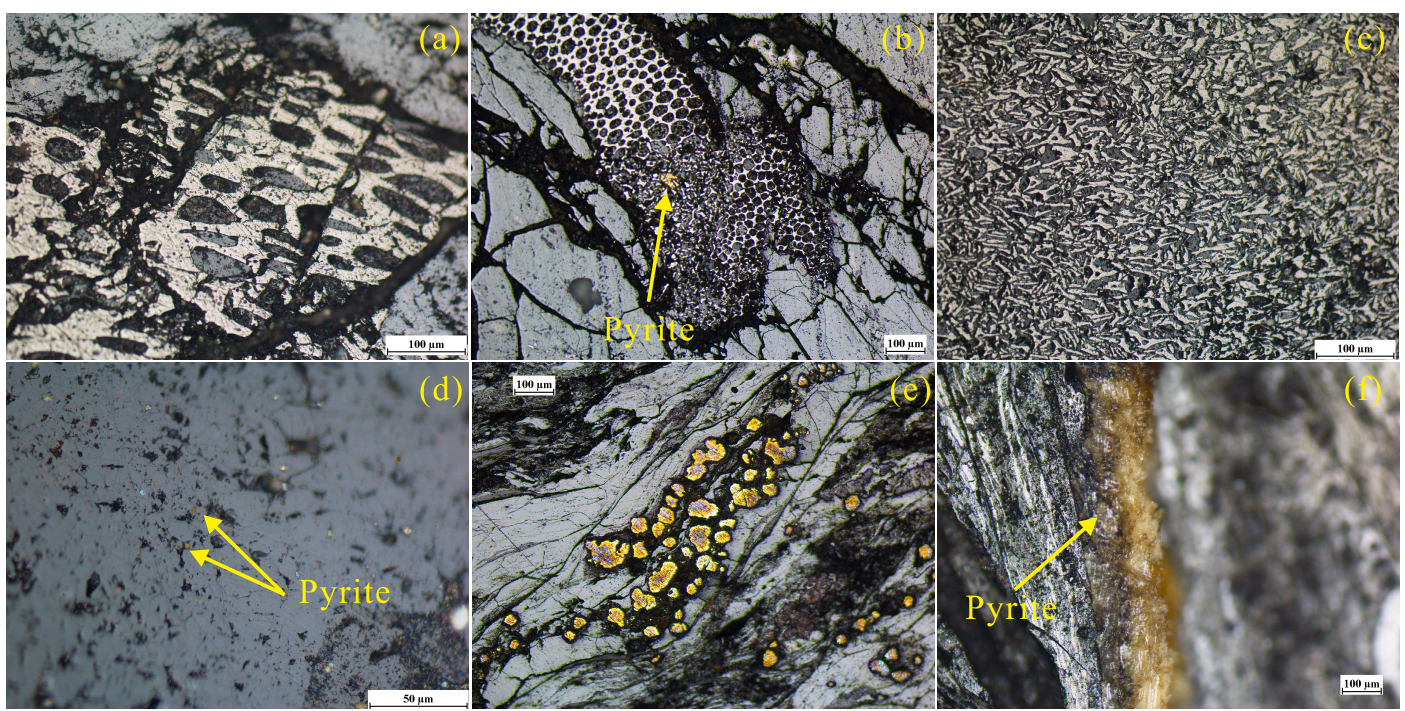

Figure 5. Minerals in fault-related coal samples. (a) Clay minerals filling in fusinite cell in sample 1; (b) Clay minerals filling in fusinite cell in sample 2; (c) Clay minerals filling in fusinite cell in sample 3; (d,e). Lumps pyrite in sample 4 and 5 respectively; (f) Pyrite filling in cleats in sample 3.

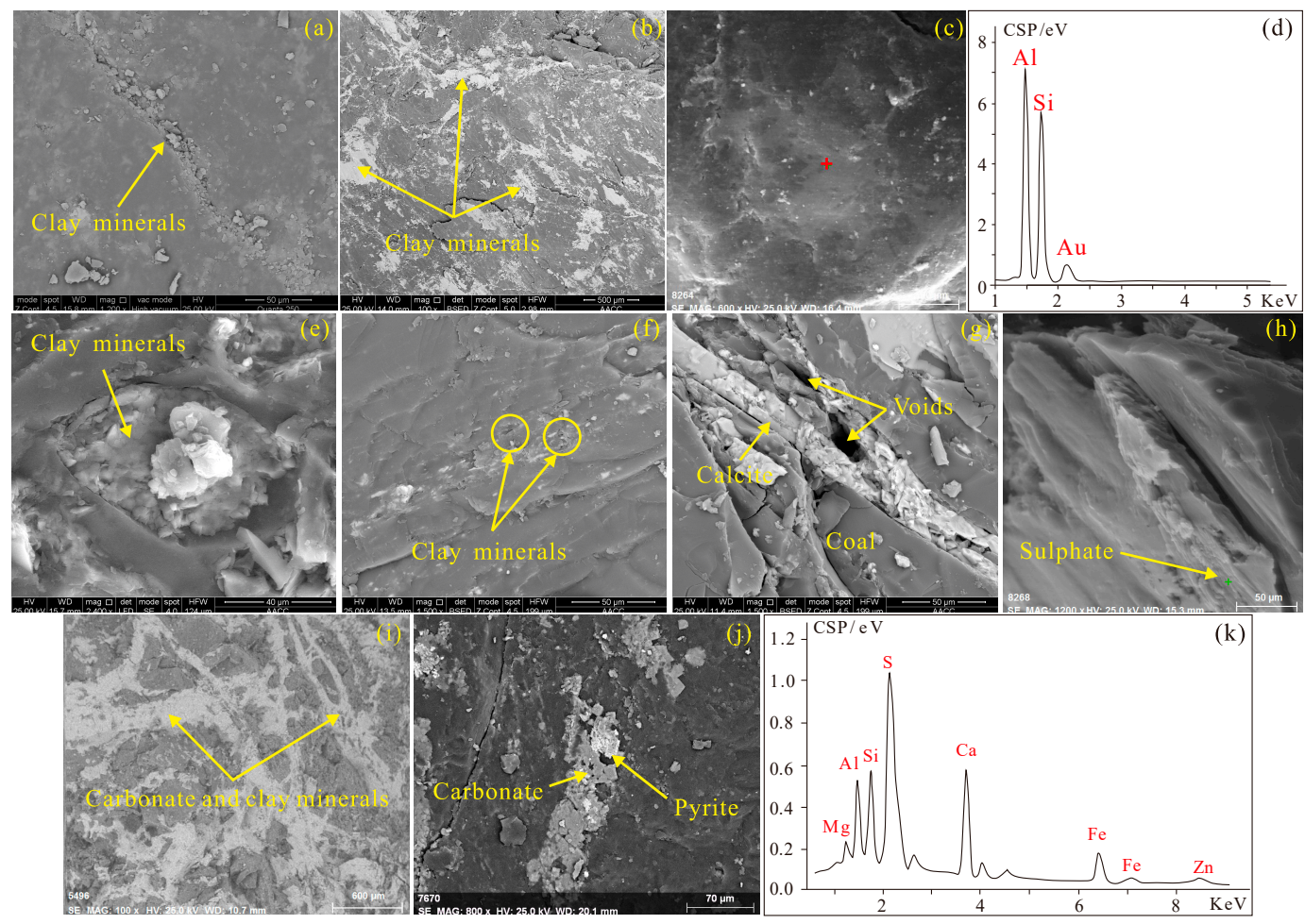

Figure 6. SEM-EDX images of minerals in fault-related coal samples. (a) Clay minerals occurring in cleat (sample 3); (b,c) clay minerals attached on the cleat surfaces filled with carbonates. (d) EDX spectrum of image c; $(\mathbf{e}, \mathbf{f})$ clay minerals filling in pore structures in sample 3; (g) distribution of calcite veins; (h) sulphate attached on cleat surface in sample; (i) the mix of carbonate and clay minerals filling in cleats; (j) the mix of carbonate, clay minerals and pyrite attached on cleat surface; (k) EDX spectrum of image $\mathrm{j}$.

With the increase of coal deformation intensity, the phenomenon of mineral mix became more frequent. In sample 3, the sulphate usually coexisted with clay minerals or carbonates in cleats and fractures (Figure 6h). Besides, the mix between clay minerals and carbonates could also be observed in cleats and fractures (Figure 6i). Nevertheless, pyrite in sample 3 occurs in the cleat of coal matrix, 
sometimes even mixed with carbonates (Figure $6 \mathrm{j}, \mathrm{k}$ ). The phenomenon of mineral mix is primarily caused by the mechanical grinding of stronger tectonic stress.

More specifically, clay minerals in samples 1 and 5 were characterized by complete intact flakes. Particle sizes of clay minerals in samples 2 and 4 were slightly reduced under the influence of tectonic stress. Clay minerals appearing in zone I were broken into porphyritic shapes with smaller particle sizes compared with those in zone II (Figure 7). In zones I and II, clay minerals were less stacked compared with those in zone III. The same morphologies of clay minerals in TDCs were also found by Song et al. [62]. The assemblage characteristics of clay minerals was more complicated in sample 3 , and dickite started to appear in sample 3 (Figure 4). The formation of dickite may be related to the thermal fluid migration associated with tectonic deformation [73].
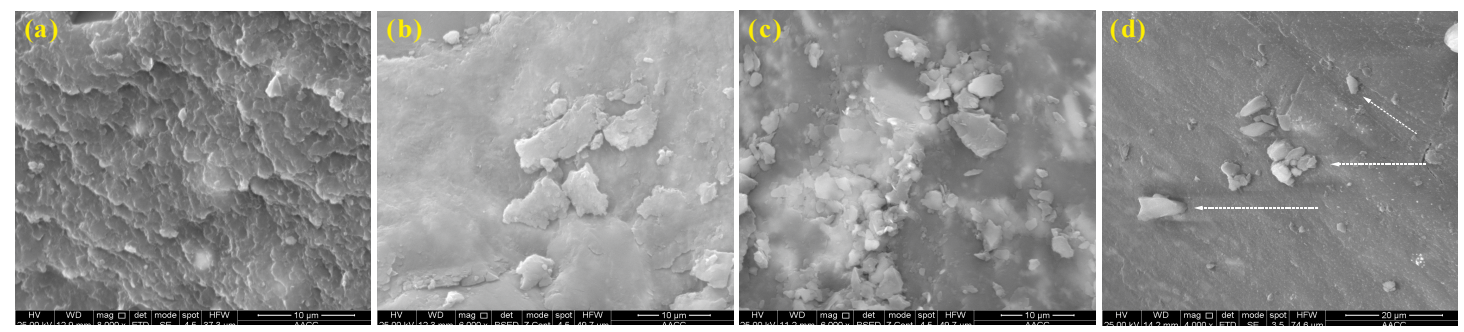

Figure 7. Morphological characteristics of clay minerals. (a) Clay minerals developed in zone III. (b) Clay minerals developed in zone II. (c) Clay minerals developed in zone I. (d) Sliding of clay minerals on frictional mirror surface of sample 3 (arrows refer to mobile direction of clay minerals).

\subsection{Distribution of Oxides of Major Elements}

Contents of $\mathrm{SiO}_{2}, \mathrm{CaO}$ and $\mathrm{Al}_{2} \mathrm{O}_{3}$ were much higher than the contents of other oxides of major elements, which is consistent with the XRD result that clay minerals, carbonates and quartz were the main minerals developed in fault-related coals (Table 2, Figure 4). Higher $\mathrm{SiO}_{2} / \mathrm{Al}_{2} \mathrm{O}_{3}$ ratios of the five samples (compared with theoretical ratio of kaolinite (1.18)) illustrated the existence of free $\mathrm{SiO}_{2}$ [50]. Oxides of major elements in fault-related coal samples did not show obvious variation regularity (Figure 8).

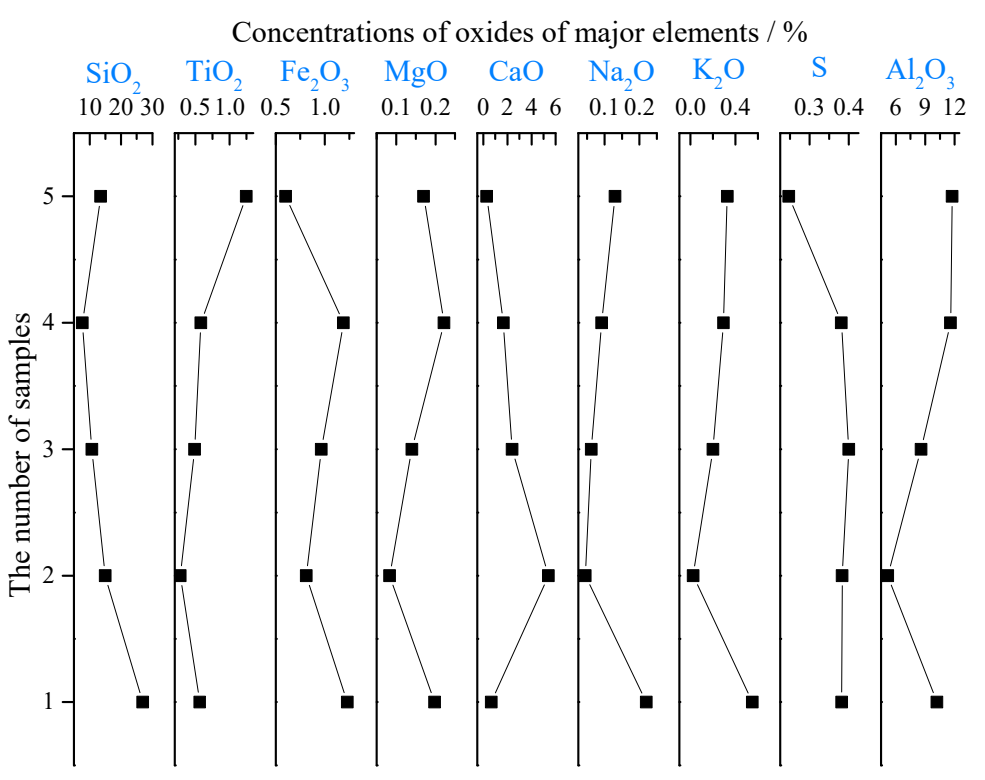

Figure 8. Distribution of oxides of major elements. 
Table 2. Oxides of major elements (\%) in fault-related coal samples.

\begin{tabular}{cccccc}
\hline Sample & $\mathbf{1}$ & $\mathbf{2}$ & $\mathbf{3}$ & $\mathbf{4}$ & $\mathbf{5}$ \\
\hline $\mathrm{SiO}_{2}$ & 26.92 & 14.95 & 10.7 & 7.68 & 13.55 \\
$\mathrm{TiO}_{2}$ & 1.25 & 0.583 & 0.491 & 0.283 & 0.566 \\
$\mathrm{Al}_{2} \mathrm{O}_{3}$ & 11.77 & 11.6 & 8.59 & 5.18 & 10.2 \\
$\mathrm{Fe}_{2} \mathrm{O}_{3}$ & 0.601 & 1.19 & 0.966 & 0.8113 & 1.23 \\
$\mathrm{MgO}$ & 0.17 & 0.222 & 0.14 & 0.083 & 0.198 \\
$\mathrm{CaO}$ & 0.288 & 1.66 & 2.39 & 5.406 & 0.667 \\
$\mathrm{Na}_{2} \mathrm{O}$ & 0.13 & 0.092 & 0.062 & 0.045 & 0.22 \\
$\mathrm{~K}_{2} \mathrm{O}$ & 0.327 & 0.294 & 0.2 & 0.023 & 0.551 \\
$\mathrm{~S}$ & 0.247 & 0.381 & 0.4 & 0.383 & 0.382 \\
\hline
\end{tabular}

\subsection{Distribution of Trace Elements}

\subsubsection{Distribution of Rare Earth Elements (REE)}

REE in this research included La, Ce, Pr, Nd, Sm, Eu, Gd, Tb, Dy, Y, Ho, Er, Tm, Yb, and Lu. It is worth noting that $Y$ with a very similar ion radius as Ho was included in REE as well [74]. REE in fault-related coals were subdivided into three groups, viz. light (LREE: $\mathrm{La}, \mathrm{Ce}, \mathrm{Pr}, \mathrm{Nd}$, and Sm), medium (MREE: Eu, Gd, Tb, Dy, and Y), and heavy (HREE: Ho, Er, Tm, Yb, and Lu) rare earth elements [75]. Concentrations of REE were normalized to the average value for upper continental crust as reported by Taylor and McLennan [76] (Figure 9).

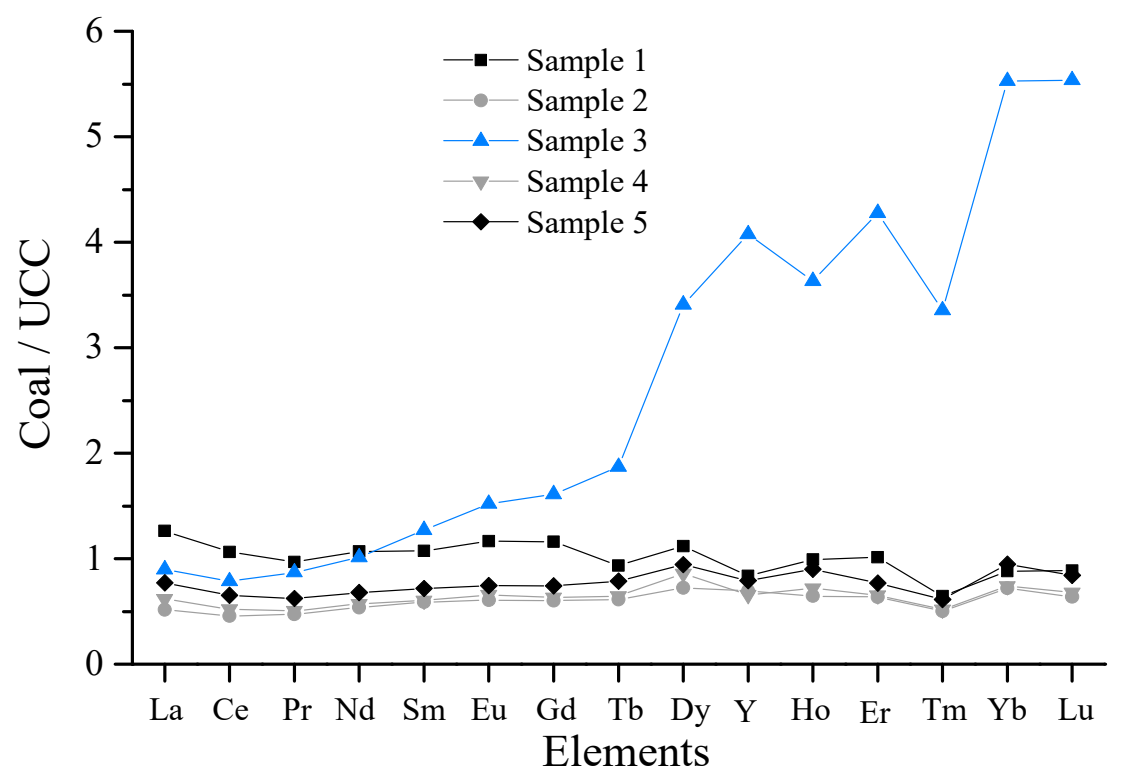

Figure 9. Distribution of normalized REE in five samples.

Interference of $\mathrm{Ba}$ on the anomalies of Eu should be clarified to ensure the reliability of data from ICP-MS analysis [74]. Fortunately, the ratios of $\mathrm{Ba} / \mathrm{Eu}$ for the five samples were all lower than 1000 (Table 3), indicating that the interference of Ba could be ignored [77].

Table 3. Ratios of $\mathrm{Ba} / \mathrm{Eu}$ of five coal samples.

\begin{tabular}{cccccc}
\hline Samples & $\mathbf{1}$ & $\mathbf{2}$ & $\mathbf{3}$ & $\mathbf{4}$ & $\mathbf{5}$ \\
\hline $\mathrm{Ba} / \mathrm{Eu}$ & 374.00 & 223.64 & 160.71 & 294.92 & 246.27 \\
\hline
\end{tabular}


Calculated parameters of REE help to understand their distribution patterns. The $\mathrm{La}_{\mathrm{N}} / \mathrm{Sm}_{\mathrm{N}}$ ratio of samples 2-5 was higher than the $\mathrm{Gd}_{\mathrm{N}} / \mathrm{Yb}_{\mathrm{N}}$ ratio (Table 4 ), indicating that the fraction degree of elements $\mathrm{La}-\mathrm{Eu}$ was higher than that of elements $\mathrm{Gd}-\mathrm{Lu}$ in samples 2-5. Similarly, $\mathrm{Ce}_{\mathrm{N}} / \mathrm{Yb}_{\mathrm{N}}$ of coals was much lower than the average value (4.6) [78], which indicated the enrichment of HREE and MREE compared with LREE. The distribution patterns of REE in samples 2-5 were H-type with $\mathrm{La}_{\mathrm{N}} / \mathrm{Lu}_{\mathrm{N}}$ lower than 1 . In sample 1 , distribution pattern of REE belonged to L-type $\left(\mathrm{La}_{\mathrm{N}} / \mathrm{Lu}_{\mathrm{N}}>1\right)$. Samples with H-type REE were probably affected by natural waters circulating in the coal basins (especially for sample 3 with $\mathrm{La}_{\mathrm{N}} / \mathrm{Lu}_{\mathrm{N}}=0.16$ ) [74,75], which is consistent with the above analysis and the hypothesis proposed by Yang et al [66]. Weak positive $\mathrm{Eu}$ anomalies $\left(\mathrm{Eu}_{\mathrm{N}} / \mathrm{Eu}_{\mathrm{N}}{ }^{*}\right.$ ranging from 1.01 to 1.13) illustrated that coals in the fault zone were less affected by reducing conditions and high temperature (>250 degrees). $\mathrm{Y}_{\mathrm{N}} / \mathrm{Ho}_{\mathrm{N}}$ in Chinese coal commonly shows very weak anomalies [74]. However, Y concentration in sample 3 showed obvious anomalies in comparison with others. Weak Ce anomalies (0.89-0.93) were observed in the five samples, indicating that the source origin of coals in the fault zone was terrigenous materials [74].

Table 4. Parameters calculation of normalized REE concentrations.

\begin{tabular}{ccccccccc}
\hline Samples & $\mathbf{L a}_{\mathbf{N}} / \mathbf{S m}_{\mathbf{N}}$ & $\mathbf{G d}_{\mathbf{N}} / \mathbf{Y b}_{\mathbf{N}}$ & $\mathrm{Ce}_{\mathbf{N}} / \mathbf{Y b}_{\mathbf{N}}$ & $\mathbf{L a}_{\mathbf{N}} / \mathrm{Lu}_{\mathbf{N}}$ & $\mathrm{Gd}_{\mathbf{N}} / \mathrm{Lu}_{\mathbf{N}}$ & $\mathrm{Ce}_{\mathbf{N}} / \mathrm{Ce}_{\mathbf{N}}{ }^{*}$ & $\mathbf{E u}_{\mathbf{N}} / \mathbf{E u}_{\mathbf{N}}{ }^{*}$ & $\mathbf{Y}_{\mathbf{N}} / \mathbf{H o}_{\mathbf{N}}$ \\
\hline 1 & 1.18 & 1.31 & 1.21 & 1.42 & 1.31 & 0.93 & 1.13 & 0.84 \\
2 & 0.88 & 0.84 & 0.63 & 0.81 & 0.94 & 0.91 & 1.02 & 1.07 \\
3 & 0.70 & 0.29 & 0.14 & 0.16 & 0.29 & 0.87 & 1.04 & 1.12 \\
4 & 1.02 & 0.86 & 0.70 & 0.91 & 0.93 & 0.90 & 1.07 & 0.91 \\
5 & 1.07 & 0.78 & 0.69 & 0.91 & 0.88 & 0.92 & 1.01 & 0.88 \\
\hline
\end{tabular}

Note: $\mathrm{Eu}_{\mathrm{N}} / \mathrm{Eu}_{\mathrm{N}}{ }^{*}=\mathrm{Eu}_{\mathrm{N}} /\left(0.5 \mathrm{Sm}_{\mathrm{N}}+0.5 \mathrm{Gd}_{\mathrm{N}}\right)$, where $\mathrm{Eu}_{\mathrm{N}}$ refers to normalized concentration of element $\mathrm{Eu}$.

Concentration coefficients (CCs) (which refer to ratios of concentrations of trace elements in fault-related coals to regional value) of trace elements in coal are useful parameters for estimating relative enrichment of those elements. Regional concentrations of trace elements provided by Zheng et al. $[79,80]$ are used as a reference. According to the categorization scheme proposed by Dai et al. [74,81,82], CCs of fault-related coals were classified into four categories: enriched $(5<\mathrm{CC}<10)$, slightly enriched $(2<C C<5)$, normal $(0.5<C C<2)$, and depleted $(C C<0.5)$. Average CCs of trace elements in samples 1 and 5 were used to represent CCs in zone III, and average CCs of samples 2 and 4 were applied to characterize CCs in zone II. Figure 10 shows that elements La-Gd were distributed in the three zones with normal value. Partial MREE (Tb, Dy and Y) and HREE were classified as enriched or slightly enriched types in Zone I. CCs of REE in zones II and III were all in the range of 0.5-2 without any exception.

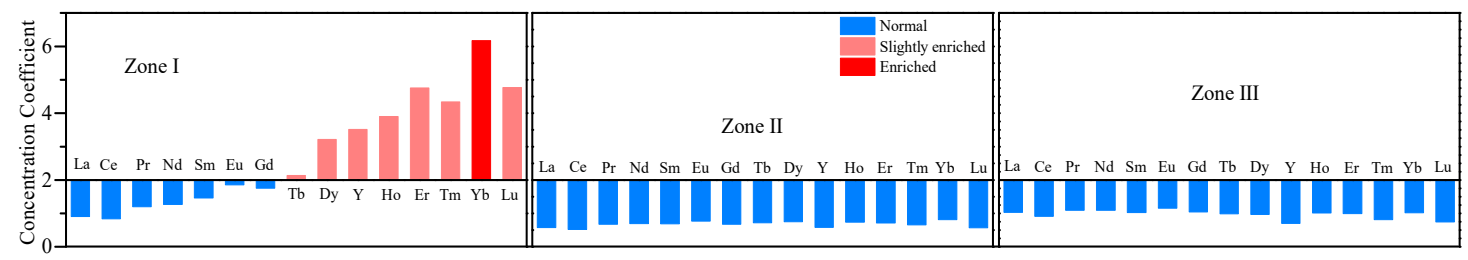

Figure 10. Distribution of CCs of REE in three subdivided zones.

Comparison of diverse TDCs showed that HREE and MREE were highly concentrated in sample 3. Concentrations of HREE and MREE in samples 2 and 4 were lower than those in samples 1 and 5 in zone II (Figure 11a, Table 5). Concentrations of LREE were higher in samples 1, 3 and 5, which is different from the distribution characteristics of HREE and MREE (Figure 11b). 

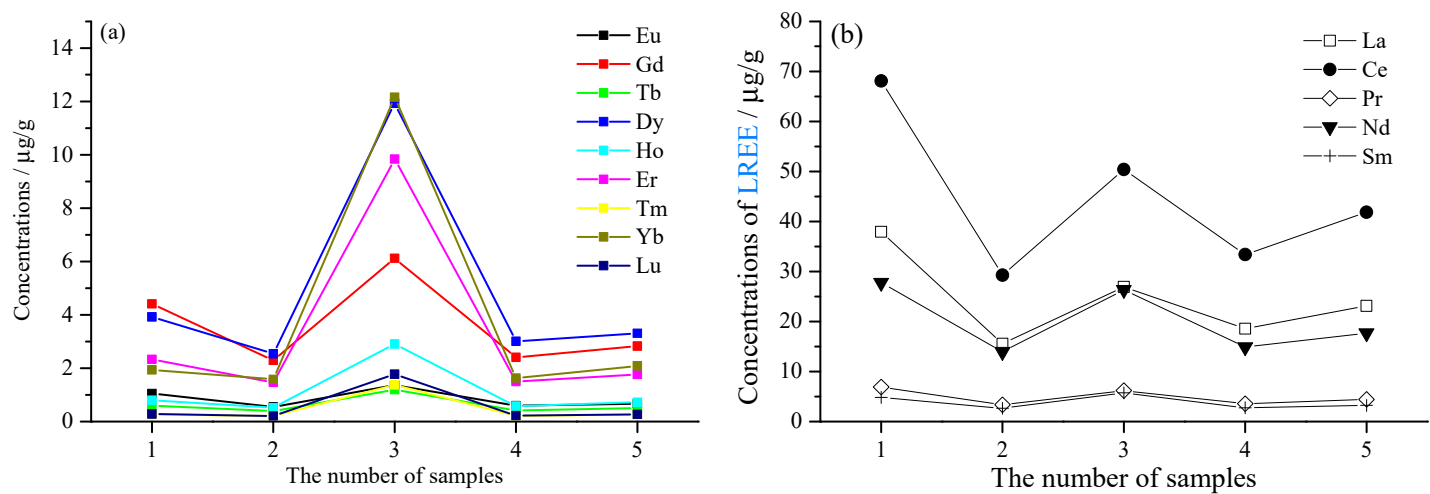

Figure 11. Distribution of REE in diverse fault-related coals. (a) Distribution of HREE and MREE in different fault-related coals. (b) Distribution of LREE in different fault-related coals.

Table 5. Concentrations of trace elements $(\mu \mathrm{g} / \mathrm{g})$ in fault-related coal samples.

\begin{tabular}{cccccccccccc}
\hline Sample & $\mathbf{1}$ & $\mathbf{2}$ & $\mathbf{3}$ & $\mathbf{4}$ & $\mathbf{5}$ & Sample & $\mathbf{1}$ & $\mathbf{2}$ & $\mathbf{3}$ & $\mathbf{4}$ & $\mathbf{5}$ \\
\hline $\mathrm{Li}$ & 10 & 11 & 32 & 16 & 23 & $\mathrm{Ba}$ & 374 & 123 & 225 & 174 & 165 \\
$\mathrm{Be}$ & 1.6 & 1.1 & 6.6 & 1.2 & 1.6 & $\mathrm{La}$ & 38 & 16 & 27 & 19 & 23 \\
$\mathrm{Sc}$ & 7.3 & 4.0 & 19 & 6.1 & 8.0 & $\mathrm{Ce}$ & 68 & 29 & 50 & 33 & 42 \\
$\mathrm{Cr}$ & 39 & 18 & 84 & 28 & 30 & $\mathrm{Pr}$ & 6.9 & 3.4 & 6.2 & 3.6 & 4.4 \\
$\mathrm{Mn}$ & 9.8 & 6.9 & 43 & 28 & 19 & $\mathrm{Nd}$ & 28 & 14 & 26 & 15 & 18 \\
$\mathrm{Co}$ & 19 & 22 & 11 & 16 & 18 & $\mathrm{Sm}$ & 4.8 & 2.6 & 5.7 & 2.7 & 3.2 \\
$\mathrm{Ni}$ & 14 & 15 & 14 & 16 & 15 & $\mathrm{Eu}$ & 1.0 & 0.55 & 1.4 & 0.59 & 0.67 \\
$\mathrm{Cu}$ & 29 & 18 & 45 & 18 & 20 & $\mathrm{Gd}$ & 4.4 & 2.3 & 6.1 & 2.4 & 2.8 \\
$\mathrm{Zn}$ & 32 & 8.4 & 96 & 12 & 33 & $\mathrm{~Tb}$ & 0.60 & 0.39 & 1.2 & 0.41 & 0.51 \\
$\mathrm{Ga}$ & 11 & 8.2 & 15 & 8.5 & 8.9 & $\mathrm{Dy}$ & 3.9 & 2.5 & 12 & 3.0 & 3.3 \\
$\mathrm{Rb}$ & 17 & 1.9 & 9.3 & 8.1 & 9.0 & $\mathrm{Ho}$ & 0.80 & 0.52 & 2.9 & 0.58 & 0.72 \\
$\mathrm{Sr}$ & 70 & 86 & 68 & 360 & 81 & $\mathrm{Er}$ & 2.3 & 1.5 & 9.8 & 1.5 & 1.8 \\
$\mathrm{Y}$ & 18 & 15 & 90 & 14 & 17 & $\mathrm{Tm}$ & 0.27 & 0.21 & 1.4 & 0.21 & 0.25 \\
$\mathrm{Nb}$ & 8.4 & 4.3 & 19 & 5.5 & 6.8 & $\mathrm{Yb}$ & 1.9 & 1.6 & 12 & 1.6 & 2.1 \\
$\mathrm{Mo}$ & 2.7 & 4.5 & 1.4 & 5.2 & 3.5 & $\mathrm{Lu}$ & 0.28 & 0.21 & 1.8 & 0.22 & 0.27 \\
$\mathrm{Cd}$ & 0.08 & 0.04 & 0.12 & 0.05 & 0.08 & $\mathrm{Ta}$ & 0.70 & 0.34 & 1.6 & 0.34 & 0.60 \\
$\mathrm{In}$ & 0.04 & 0.02 & 0.07 & 0.03 & 0.04 & $\mathrm{~W}$ & 0.96 & 0.75 & 1.9 & 0.91 & 0.92 \\
$\mathrm{Cs}$ & 1.2 & 0.40 & 0.71 & 1.0 & 1.2 & $\mathrm{Tl}$ & 0.45 & 0.09 & 0.15 & 0.15 & 0.13 \\
$\mathrm{~Pb}$ & 21 & 7.3 & 35 & 7.5 & 13 & $\mathrm{Th}$ & 5.7 & 3.0 & 15 & 3.9 & 6.6 \\
$\mathrm{Bi}$ & 0.22 & 0.19 & 0.36 & 0.16 & 0.22 & $\mathrm{U}$ & 2.1 & 1.1 & 8.0 & 1.5 & 1.5 \\
\hline
\end{tabular}

\subsubsection{Distribution of Other Trace Elements}

In zone I, CCs of elements $\mathrm{Li}, \mathrm{Be}, \mathrm{Sc}, \mathrm{Cr}, \mathrm{Zn}, \mathrm{Nb}, \mathrm{Pb}, \mathrm{Ta}, \mathrm{Th}$, and $\mathrm{U}$ ranged from 2 to 5 indicating a slight enrichment of those elements (Figure 12). Elements $\mathrm{Li}, \mathrm{Be}, \mathrm{Sc}, \mathrm{Cr}, \mathrm{Nb}, \mathrm{Ta}$, and $\mathrm{U}$ in zones II and III are within the global average values $(0.5<\mathrm{CC}<2)$. Elements $\mathrm{Zn}, \mathrm{Pb}$ and Th were depleted $(\mathrm{CC}<0.5)$ in zone II followed by normal CCs in zone III. CCs of elements Ni, Ga, In, Cs, Ba, W, and Tl were all at a normal level in the three zones, while CC of element Bi was lower than 0.5 in the three zones. Elements $\mathrm{Cu}$ and $\mathrm{Rb}$ with normal values in zones I and III were depleted in zone II. Element $\mathrm{Sr}$ with normal CCs in zones II and III was slightly enriched in zone II. Element Co which was slightly enriched in zones II and III showed normal concentration in zone I. Element Mo, depleted in zone I, showed constant normal distribution in zones II and III, while the distribution of element Cd was inverse in the three zones.

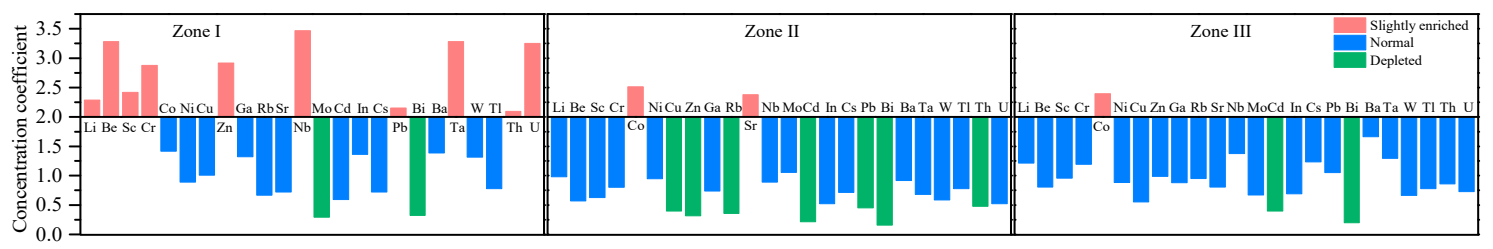

Figure 12. Distribution of CCs of REE in three subdivided zones. 
For different types of TDCs, elements $\mathrm{Li}, \mathrm{Be}, \mathrm{Sc}, \mathrm{Cr}, \mathrm{Cu}, \mathrm{Mn}, \mathrm{Zn}, \mathrm{Ga}, \mathrm{Nb}, \mathrm{Cd}, \mathrm{Bi}, \mathrm{Ta}$, W, and U were significantly enriched in sample 3 (Figure 13a,b). Concentrations of elements Co and Mo were low in zone I, while they were relatively accumulated in zones II and III (Figure 13c). The distribution of elements $\mathrm{Ni}, \mathrm{Rb}, \mathrm{Sr}, \mathrm{Cs}, \mathrm{Ba}$, and Tl belonged to disordered type (Figure 14).
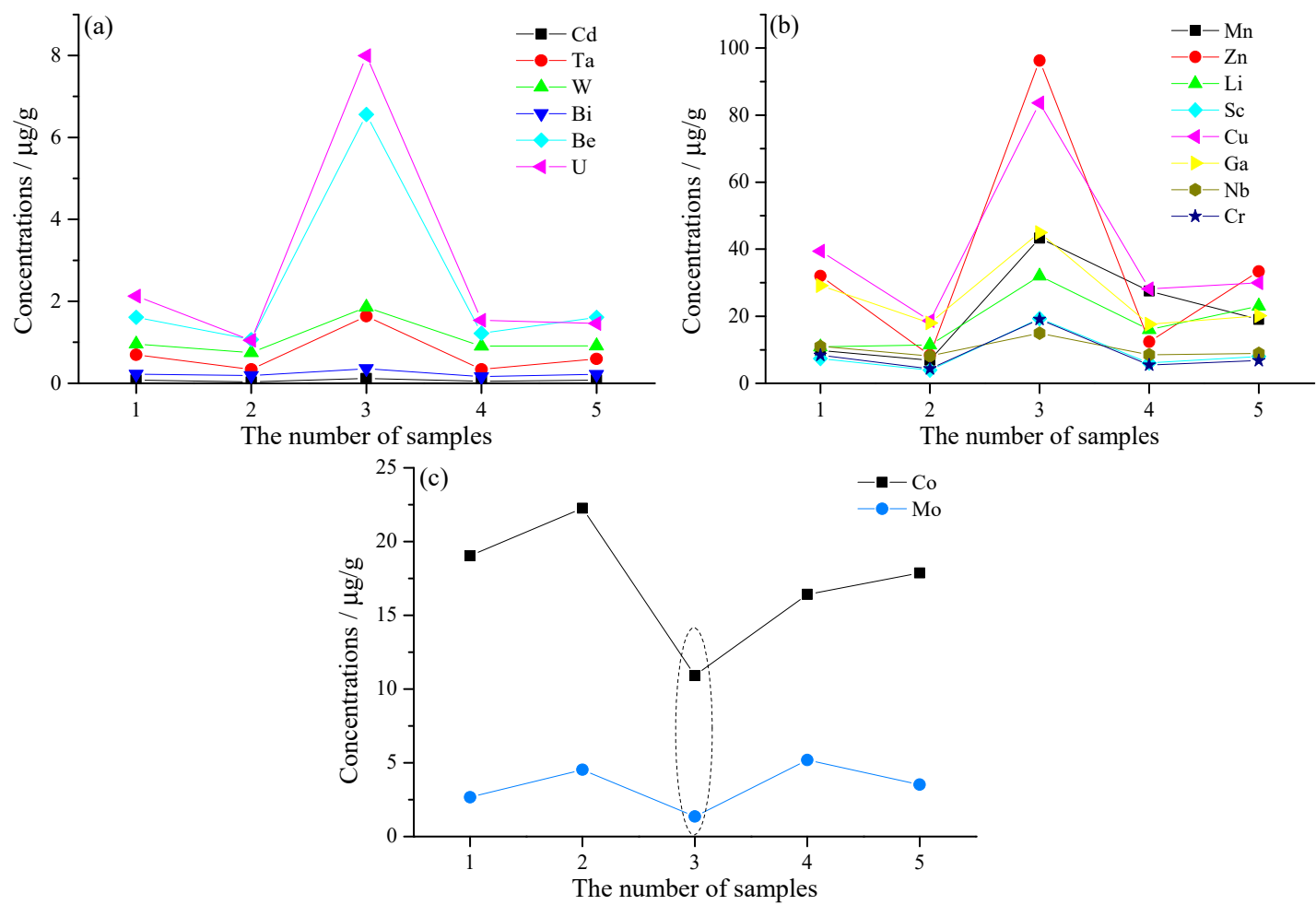

Figure 13. Distribution of accumulated and dissipated types of trace elements in the fault zone. $(\mathbf{a}, \mathbf{b})$ Distribution of accumulated type of trace elements in the fault zone. (c) Distribution of dissipated type of trace elements in the fault zone.

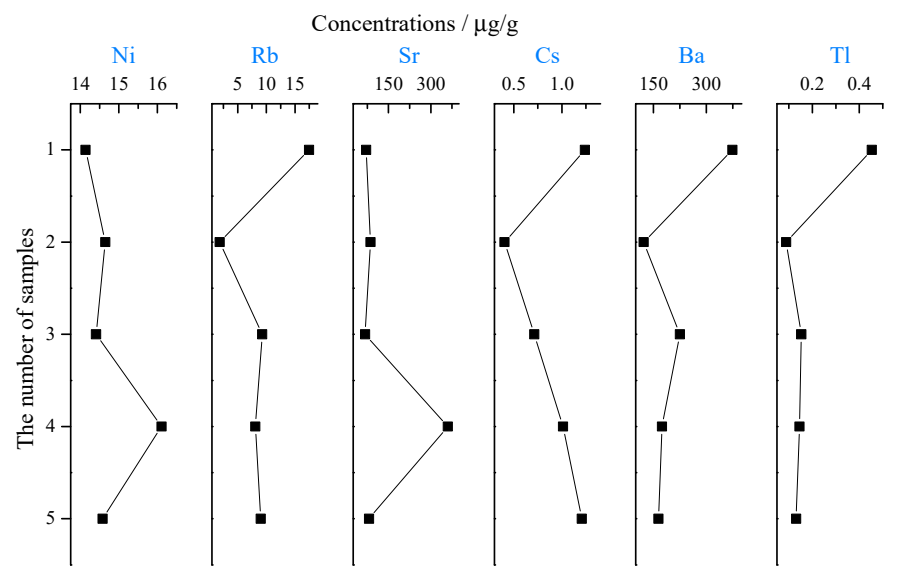

Figure 14. Distribution of disordered type of trace elements in the fault zone.

\section{Discussion}

\subsection{Elemental Geochemical Associations}

The key to understanding the differentiation mechanisms of trace elements is to determine their affinities. Concentrations of major element oxides, trace elements and ash yields were analyzed together with a hierarchical cluster analysis method (Figure 15). When 15 was adopted as the rescaled distance, all members could be classified into five groups. 


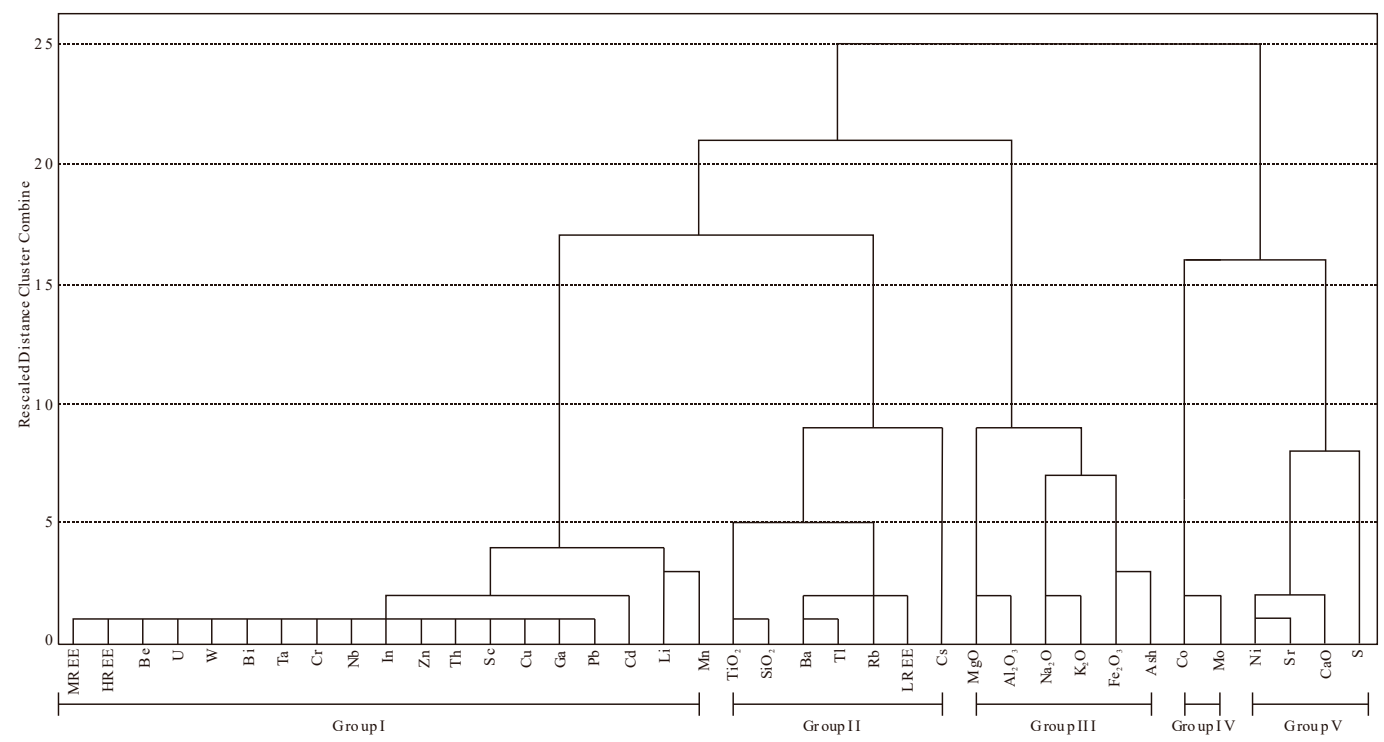

Figure 15. The family tree of hierarchical cluster analysis.

Group I included elements MREE, HREE, Be, U, W, Bi, Ta, Cr, Nb, In, Zn, Th, Sc, Cu, Ga, Pb, Cd, $\mathrm{Li}$, and $\mathrm{Mn}$. Among them, REE were found in the clay minerals attached on the cleat surfaces in sample 3 (Figure 16). Element Zn mainly occurred in pyrite according to the EDX spectrum (Figure 6j,k). Similarly, elements $\mathrm{Cu}$ and $\mathrm{Pb}$ were also closely correlated with sulfide minerals. Furthermore, the other elements that basically belong to lithophile elements also have aluminosilicate affinity to some extent as reported by Zhang et al. [83], Dai et al. [84], Tian et al. [85] and Finkelman et al. [86]. Elements in group I with significant positive anomalies were significantly influenced by thermal fluid or leached water as mentioned above.
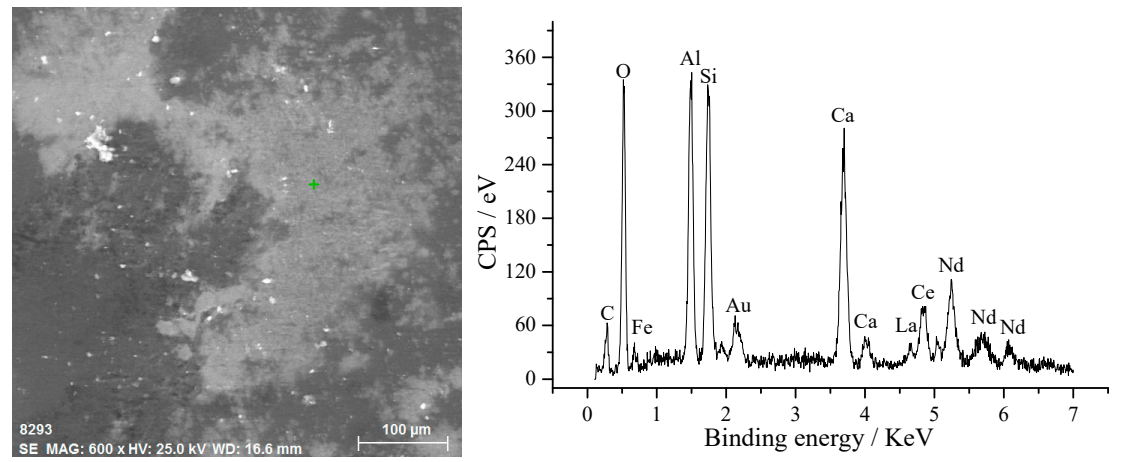

Figure 16. The SEM-EDX detection results of REE-containing minerals attached on cleat surfaces.

Group II included $\mathrm{TiO}_{2}, \mathrm{SiO}_{2}, \mathrm{Ba}, \mathrm{Tl}, \mathrm{Rb}, \mathrm{LREE}$, and Cs. Among them, the correlation coefficient between $\mathrm{TiO}_{2}$ and $\mathrm{Al}_{2} \mathrm{O}_{3}$ was 0.782 and that between $\mathrm{TiO}_{2}$ and $\mathrm{SiO}_{2}$ is 0.988 , indicating aluminosilicate affinity. Besides, the SEM-EDX results showed that LREE could be directly observed in clay minerals (Figure 16). In brief, elements in the group all showed aluminosilicate affinity.

Group III included $\mathrm{MgO}, \mathrm{Al}_{2} \mathrm{O}_{3}, \mathrm{Na}_{2} \mathrm{O}, \mathrm{K}_{2} \mathrm{O}, \mathrm{Fe}_{2} \mathrm{O}_{3}$, and ash yield. $\mathrm{Fe}_{2} \mathrm{O}_{3}$ mainly occurred in dolomite and pyrite in those fault-related samples. $\mathrm{Al}_{2} \mathrm{O}_{3}$ is the major component of clay minerals. Besides, $\mathrm{K}_{2} \mathrm{O}$ could be found in clay minerals, while, $\mathrm{MgO}$ was observed in both clay minerals and carbonates. Therefore, oxides of major elements in groups III were closely correlated with clay minerals or carbonates.

Group IV only included Co and Mo. Elements Co and Mo were strongly correlated with $C_{\text {daf }}$ $\left(\mathrm{r}_{\mathrm{C} \text { daf }}=0.806\right.$ and 0.785 respectively), indicating a possible organic affinity. $\mathrm{Ni}, \mathrm{Sr}, \mathrm{CaO}$, and $\mathrm{S}$ in group $\mathrm{V}$ were poorly correlated with ash yield or $\mathrm{Al}_{2} \mathrm{O}_{3}$. EDX data showed that element $\mathrm{Ni}$ was detected 
in the mix of sulphate minerals and carbonates, while Ni could not be detected in sole carbonate (Figure 6h, Table 6). Therefore, elements Ni and Sr were probably associated with sulphate minerals.

Table 6. EDX data for sulphate in sample 3.

\begin{tabular}{cccc}
\hline Element & Concentration/wt.\% & Element & Concentration/wt.\% \\
\hline $\mathrm{O}$ & 18.07 & $\mathrm{Na}$ & 0.02 \\
$\mathrm{Al}$ & 2.06 & $\mathrm{Mg}$ & 0.01 \\
$\mathrm{C}$ & 49.68 & $\mathrm{~K}$ & 0.02 \\
$\mathrm{Si}$ & 0.66 & $\mathrm{Ca}$ & 21.5 \\
$\mathrm{~S}$ & 6.46 & $\mathrm{Fe}$ & 0.9 \\
$\mathrm{Ni}$ & 0.07 & & \\
\hline
\end{tabular}

\subsection{Accumulation Mechanisms of HREE, MREE and Related Elements}

\subsubsection{Evidences of the Injection of Solutions}

Local distribution of trace elements might be influenced by the invasion of solutions with higher concentrations of related elements [49]. The presence of dickite in sample 3 (Figure 4) might be related to the thermal fluid migration associated with tectonic deformation [73]. Similarly, in zone I, the developed fracture-fillings including carbonates, clay minerals and pyrite containing a higher concentration of MREE, HREE and related elements illustrated that those elements probably originated from an epigenetic process, such as the invasion hydrothermal fluids or leaching of meteoric water [50,87].

Furthermore, REE contains useful information on the epigenetic resources of related elements. For sample 3, H-type of REE $\left(\mathrm{La}_{\mathrm{N}} / \mathrm{Lu}_{\mathrm{N}}<1\right)$ with a significant $\mathrm{Y}$ positive anomaly was probably affected by invasive solutions [74,75]. Besides, $\mathrm{Yb} / \mathrm{La}(=0.45)$ of sample 3 was much larger than common word hard coal (Table 7). Furthermore, the presence of higher U/Th and Yb/La in sample 3 was also caused by the elemental redistribution related to invasive solutions with higher concentrations of related elements $[87,88]$. The hydrothermal fluid or meteoric water leaching through the overlying clay partings caused the more active elements $(\mathrm{U}$ and $\mathrm{Yb})$ to be deposited in coals [88].

Table 7. Calculated parameters of normalized REE concentrations.

\begin{tabular}{cccccc}
\hline Samples & $\mathbf{1}$ & $\mathbf{2}$ & $\mathbf{3}$ & $\mathbf{4}$ & $\mathbf{5}$ \\
\hline $\mathrm{U} / \mathrm{Th}$ & 0.37 & 0.37 & 0.53 & 0.38 & 0.23 \\
$\mathrm{Yb} / \mathrm{La}$ & 0.05 & 0.10 & 0.45 & 0.09 & 0.09 \\
\hline
\end{tabular}

\subsubsection{Migration}

Higher CCs and concentrations of HREE and MREE of sample 3 compared to other samples indicate the significant enrichment of HREE and MREE in zone I (Figures 10 and 11a). Similarly, CCs and concentrations of related elements (Be, U, W, Bi, Ta, Cr, Nb, In, Zn, Th, Sc, Cu, Ga, Pb, Cd, $\mathrm{Li}$ and $\mathrm{Mn}$ ) in sample 3 were higher than those in other samples (Figures 12 and 13a,b). Pore and cleat mineralization found in sample 3 (Figure 6a-f) can be considered another evidence of solutions movement [72,89]. Solutions migrating through coal seam carry different types of trace elements and play an important role in the enrichment of these elements [75,90,91]. Therefore, the accumulation of HREE, MREE and related elements in sample 3 was mainly associated with the invasive solutions.

The migration of solutions depends on the development of a pore-cleat system in fault-related coals. Coal samples collected around fault structures are altered by tectonic stress into TDCs with a modified pore-cleat system [32,34,53,59,61,62,92,93]. Clarifying different fluid paths in fault-related coal samples could provide useful information about the migration of solutions. Thus, total porosity data could be useful for determining the relationship between tectonic deformation and elemental enrichments in the studied samples. Pore volume and injection-ejection ratios of these coal samples could be calculated from the porosity results (Figure 17) [71,94]. As expected, the distribution of pore 
volume in fault-related coal samples was consistent with the distribution of HREE, MREE and related elements (Figures 11a and 13a,b), which confirms that the developed pore-cleat system in sample 3 was more beneficial for the movement of solutions and influx of specific trace elements.

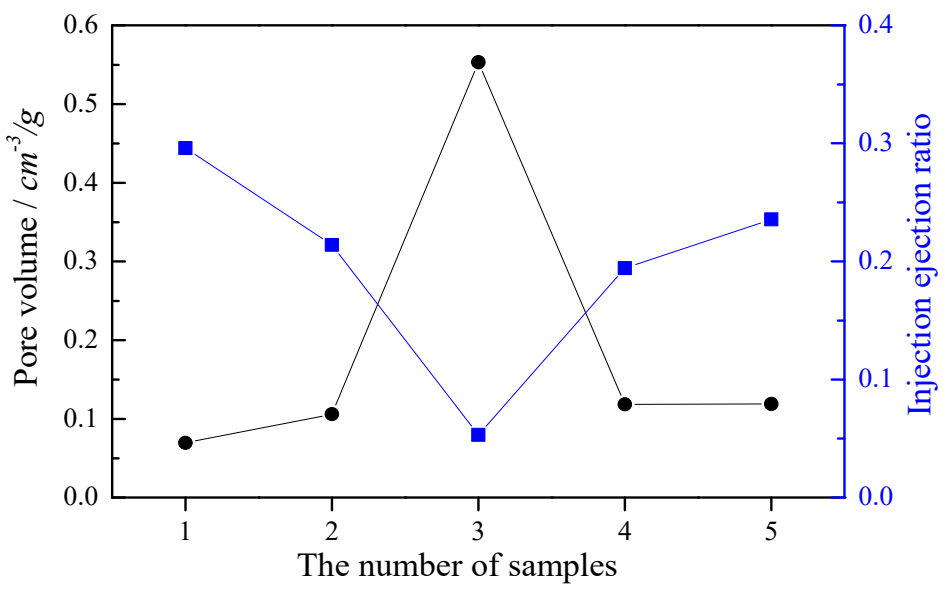

Figure 17. Distribution of pore volume and injection-ejection ratios of fault-related coal samples.

\subsubsection{Accumulation}

Sample 3 in zone I characterized by a low injection to ejection ratio had lower permeability (Figure 14) [71]. The lower permeability of sample 3 indicates that closed pore structures were likely formed under shear and compression stress or occluded by sealing minerals, viz. clay minerals (Figure 6e,f) in zone I $[95,96]$. During faulting deformation, many trace elements associated with clays and other minerals could be dissolved in acid solutions and transported through zone I [72,97], and then reprecipitated in a post-depositional pore-cleat system under alkaline condition (Figure 6a-f) [60,68]. Correspondingly, cleat-filling minerals retained and accumulated MREE; HREE and related elements occupied partial pore-cleat structures, and more closed pores and cleats were formed and the permeability of the conduit system in zone I became lower. Therefore, the solutions flowing into fault structures were limited in zone I, similar to the process occurring in fault zones of rocks [8,22,98]. The limitations of solutions in the local area could be used to explain the anomalous behavior that only occurred in zone I.

Pore-cleat mineralization could not fully explain the accumulation of HREE, MREE and related elements, because the concentration of $\mathrm{Al}_{2} \mathrm{O}_{3}$ (major constituent of clay minerals that is the host of these trace elements) in sample 3 was not the highest one. Clay minerals with special physical and chemical properties are sensitive to tectonic stress [99]. Similarly, decreasing particle sizes and less stacked laminar structures of clay minerals were also found in zones II and I, suggesting that strong mechanical grinding and dislocating of tectonic stress acted not only on the coal matrix, but also on minerals occurring in the coal (Figure $7 \mathrm{a}-\mathrm{c}$ ). Laminar clay minerals were preferentially disrupted along basal planes including layer-parallel extension and layer-parallel shortening [100], especially on the friction mirror surfaces (Figure $7 \mathrm{~d}$ ). Coating of clay minerals on the friction mirror surfaces further sealed the pore-cleat system of coal, which resulted in the reduction of permeability in zone I (Figure 6b,c) $[25,101]$.

Studies on experimental and natural clay samples showed that stress promoted the breakdown and delamination of the clay mineral layers [24,100], which exposed the oxygen and hydroxyl planes beneficial to the sorption of elements [102]. It is necessary to evaluate whether similar chemical alterations (viz. hydroxyl exposure) of clay minerals occur in fault-related coals as well. FT-IR spectra over the range of $3600-3700 \mathrm{~cm}^{-1}$ provide useful information about hydroxyl groups of clay minerals in coal [103]. Adsorption bands at $3620 \mathrm{~cm}^{-1}, 3650 \mathrm{~cm}^{-1}, 3670 \mathrm{~cm}^{-1}$, and $3695 \mathrm{~cm}^{-1}$ were assigned to the stretching vibration of inner hydroxyl, outer hydroxyl and inner-surface hydroxyl groups, respectively [104,105]. 
Figure 18 shows that concentrations of three types of hydroxyl groups in sample 3 were significantly higher than those of other samples. However, the concentration of $\mathrm{Al}_{2} \mathrm{O}_{3}$ in sample 3 was not the highest one, suggesting that the increase in number of hydroxyl groups in sample 3 was not due to the content variation of clay minerals (Figure 8). Nacrite, kaolinite and dickite found in fault-related coals all belong to the kaolinite group with similar lamellar structures [106-108], indicating that diverse assemblage characteristics of clay minerals in fault-related coals also did not lead to the increase in number of hydroxyl groups in zone I. To the best of our knowledge, an increase in number of hydroxyl groups of clay minerals is mainly due to the exposure of oxygen and hydroxyl planes by shear stress.

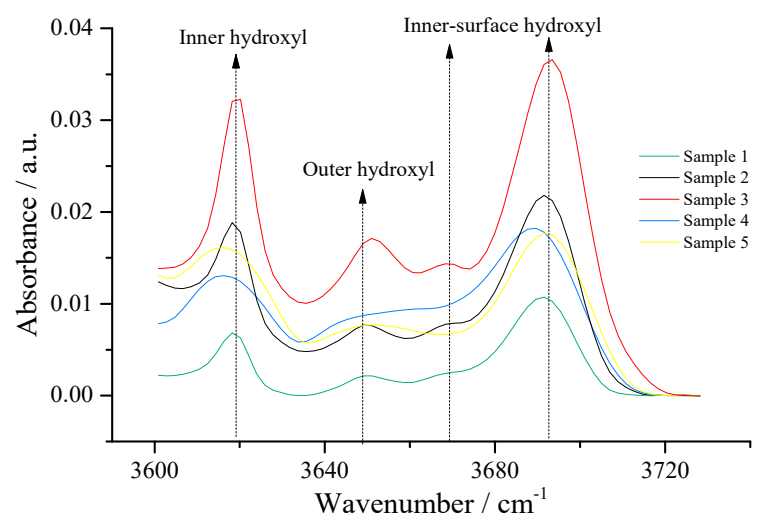

Figure 18. Characteristics of various types of hydroxyl groups of fault-related coal samples.

HREE, MREE and related elements that migrated into the coal seam in a dissolved form could be mostly adsorbed by clay minerals, which has been reported by previous studies and confirmed by relevant experimental studies [78,86,109-114]. Experimental studies have shown that the sorption of REE and related elements mainly depended on adsorption sites of clay minerals, namely, hydroxyl units on Al-O hexahedron or Si-O tetrahedron sheets [115-117]. An increase in the three types of hydroxyl groups supplied more edge and basal adsorption sites for trace elements in sample 3 , which resulted in the accumulation of HREE, MREE and related elements in zone I. Besides, sorption experiments showed that HREE and MREE were more readily absorbed by clay minerals than LREE by clay minerals [118]. Therefore, HREE and MREE were more accumulated in sample 3 than LREE.

Furthermore, nano-scale clay minerals are known to develop in fault rocks [25,119]. Previous studies showed that scaly exfoliation of clay minerals usually led to the formation of nano-scale flakes under the influence of shear stress [24,120]. High-resolution transmission electron microscopy results showed that nano-scale clay minerals also developed in sample 3, which might result from compression-shear stress exfoliation (Figure 19). Chemical activity and specific surface of clay minerals were significantly enhanced due to the nano size, making them an important carrier of trace elements [121-123].

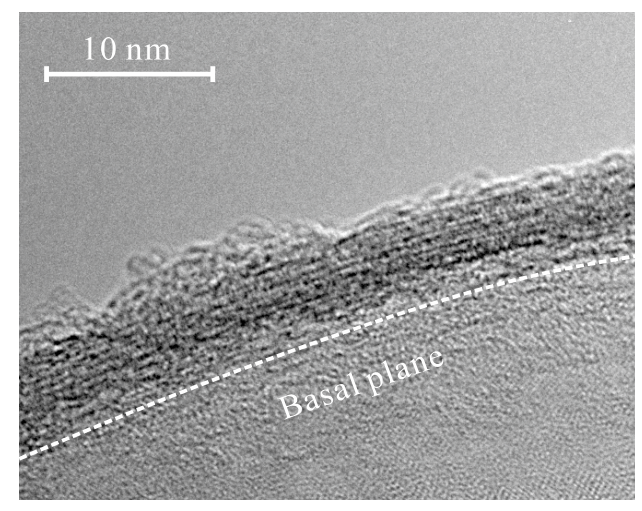

Figure 19. Nano-scale clay mineral in zone I. 


\subsection{Dissipation Mechanism of Elements Co and Mo}

Extraction experiments showed that a large proportion of Co was associated with organic components (at least 20\%) [86,124]. The concentration of Mo in lighter gravity fractions of sink-float experiments confirmed that Mo was at least partially associated with organic matter [86,125-127]. Co and Mo bonded to the organic compounds of coal which usually undergo ion-exchange with protons of oxygen functional groups, viz. carboxyl and phenolic groups $[86,128,129]$. Specific reactions between oxygen functional groups and ions are given in the following equations (According to Wang et al. [129]).

$$
\begin{aligned}
& \mathrm{aCOAL}-C O O^{-}+\mathrm{M}^{\mathrm{a}+}(\mathrm{aq}) \leftrightharpoons \mathrm{a}(\mathrm{COAL}-\mathrm{COO}) \mathrm{M}
\end{aligned}
$$

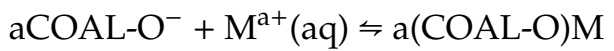

Coal molecular structures can be altered by tectonic stress, including the degradation of oxygen functional groups [28-30,130]. FT-IR is an effective method to characterize hydroxyl groups in coal chemical structures. Phenol (1100-1300 cm-1$)$ and carboxyl $\left(1650-1700 \mathrm{~cm}^{-1}\right)$ can be distinguished in FT-IR spectrum ranging from $1100-1700 \mathrm{~cm}^{-1}$ [40]. The deconvolution process of FT-IR spectrum was performed using software Origin 7.5 (Figure 20a). Figure 20b shows that the molar content of phenol and carboxyl units significantly decreased in sample 3. Frictional heat generated by fault motion could lead to early-metamorphism of coal containing the degradation of oxygen functional groups [41,130,131]. According to recent research, strong ductile deformation in zone I could also change the molecular structures of coal by transformation into strain energy $[39,40,132]$. Besides, the higher $R_{\mathrm{O} \text {,max }}$ of sample 3 also indicated that the maturation degree of sample 3 was advanced by the influence of stress-induced dynamic metamorphism, including the stress degradation of functional groups (Table 1). Therefore, oxygen functional groups (phenol and carboxyl), as a relatively unstable part of the coal molecular structure, were disassociated under the action of frictional heat and ductile deformation. Synchronized variation of phenol, carboxyl, Co and Mo confirmed that these two elements are probably associated with phenol and carboxyl groups. Dissociation of phenol and carboxyl groups led to dissolution of ion-exchanged Co and Mo into migrated solutions, which caused elements Co and Mo to be depleted in sample 3 (Figure 13c).
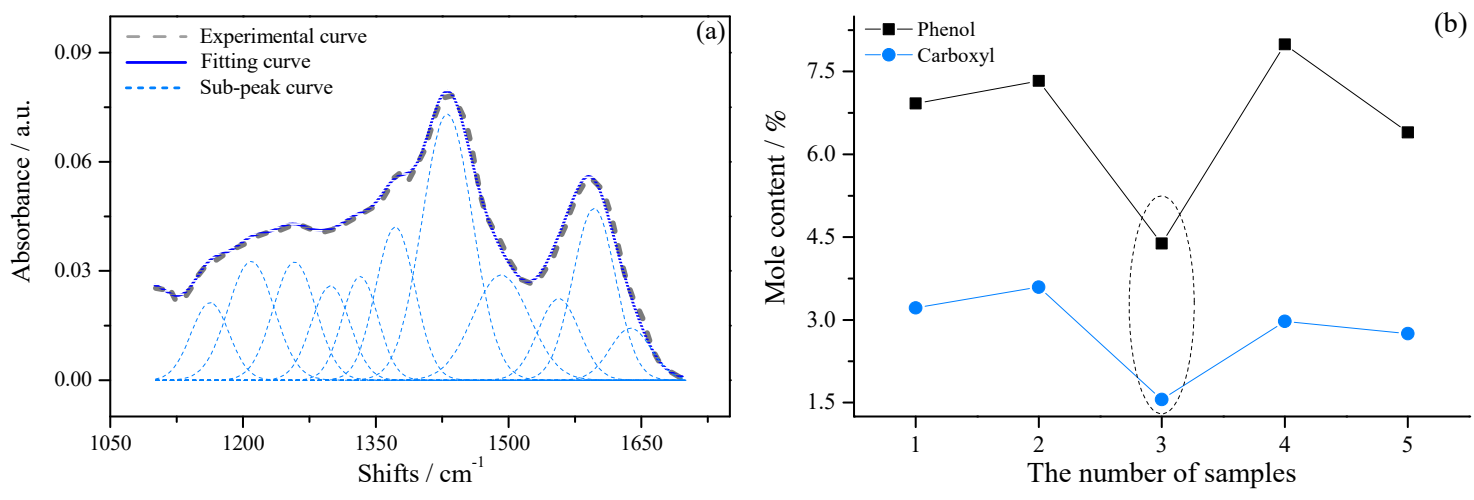

Figure 20. Distribution of phenol and carboxyl in fault-related coals. (a) Fitting of FT-IR spectrum in the range of $1100-1700 \mathrm{~cm}^{-1}$. (b) Distribution of phenol and carboxyl in fault-related coals.

\section{Conclusions}

Five typical TDC samples were collected in the same sequence within the reverse fault zone. The geophysical and geochemical characteristics of fault-related coals were analyzed and compared by using appropriate detection and analytical methods. HREE, MREE and related elements (Be, U, W, Bi, $\mathrm{Ta}, \mathrm{Cr}, \mathrm{Nb}, \mathrm{In}, \mathrm{Zn}, \mathrm{Th}, \mathrm{Sc}, \mathrm{Cu}, \mathrm{Ga}, \mathrm{Pb}, \mathrm{Cd}, \mathrm{Li}$ and $\mathrm{Mn}$ ) commonly associated with invasive solutions showed significant positive anomalies in zone I. Precipitated occlusion and stress-induced smearing of clay minerals decreased the permeability of the pore-cleat system in zone I and then limited the 
thermal fluid in zone I, which was one of the major reasons for the appearance of significant positive anomalies only in zone I. Strong compression-shear tectonic stress led to disruption and delamination of clay minerals, which enhanced the their adsorption ability for HREE, MREE and related elements in zone I. Even nano-scale clay minerals with higher specific surface area and chemical activity were exfoliated by shear stress. Elements Co and Mo with strong organic affinity were sharply dissipated in zone I, which was ascribed to the disassociation of phenol and carboxyl groups resulting from the fault motion.

Author Contributions: H.L. undertook the experiments, prepared the manuscript and analyzed the data. B.J. conceived the project and designed the experiments. All authors discussed the results and commented on the manuscript.

Funding: This research was funded by the National Natural Science Foundation of China (No. 41672147, 41430317), and the Scientific Research Foundation of Key Laboratory of Coalbed Methane Resources and Reservoir Formation Process, Ministry of Education (China University of Mining and Technology) (No. 2017-004).

Acknowledgments: We would like to thank the reviewers and editors for their constructive comments and suggestions.

Conflicts of Interest: The authors declare no conflict of interest.

\section{References}

1. Roques, C.; Aquilina, L.; Bour, O.; Maréchal, J.; Dewandel, B.; Pauwels, H.; Labasque, T.; Vergnaud-Ayraud, V.; Hochreutener, R. Groundwater sources and geochemical processes in a crystalline fault aquifer. J. Hydrol. 2014, 519, 3110-3128. [CrossRef]

2. Duan, Q.; Yang, X.; Ma, S.; Chen, J.; Chen, J. Fluid-rock interactions in seismic faults: Implications from the structures and mineralogical and geochemical compositions of drilling cores from the rupture of the 2008 Wenchuan earthquake, China. Tectonophysics 2016, 666, 260-280. [CrossRef]

3. Kuo, L.; Huang, J.; Fang, J.; Si, J.; Song, S.; Li, H.; Yeh, E. Carbonaceous Materials in the Fault Zone of the Longmenshan Fault Belt: 2. Characterization of Fault Gouge from Deep Drilling and Implications for Fault Maturity. Minerals 2018, 8, 393. [CrossRef]

4. Gajst, H.; Weinberger, R.; Zhu, W.; Lyakhovsky, V.; Marco, S.; Shalev, E. Effects of pre-existing faults on compaction localization in porous sandstones. Tectonophysics 2018, 747-748, 1-15. [CrossRef]

5. Maciel, I.; Dettori, A.; Balsamo, F.; Bezerra, F.; Vieira, M.; Nogueira, F.; Salvioli-Mariani, E.; Sousa, J. Structural Control on Clay Mineral Authigenesis in Faulted Arkosic Sandstone of the Rio do Peixe Basin, Brazil. Minerals 2018, 8, 408. [CrossRef]

6. Wilson, J.E.; Chester, J.S.; Chester, F.M. Microfracture analysis of fault growth and wear processes, Punchbowl Fault, San Andreas system, California. J. Struct. Geol. 2003, 25, 1855-1873. [CrossRef]

7. Chester, J.S.; Chester, F.M.; Kronenberg, A.K. Fracture surface energy of the Punchbowl fault, San Andreas system. Nature 2005, 437, 133-136. [CrossRef] [PubMed]

8. Pei, Y.; Paton, D.A.; Knipe, R.J.; Wu, K. A review of fault sealing behaviour and its evaluation in siliciclastic rocks. Earth Sci. Rev. 2015, 150, 121-138. [CrossRef]

9. Buatier, M.D.; Chauvet, A.; Kanitpanyacharoen, W.; Wenk, H.R.; Ritz, J.F.; Jolivet, M. Origin and behavior of clay minerals in the Bogd fault gouge, Mongolia. J. Struct. Geol. 2012, 34, 77-90. [CrossRef]

10. Arancibia, G.; Fujita, K.; Hoshino, K.; Mitchell, T.M.; Cembrano, J.; Gomila, R.; Morata, D.; Faulkner, D.R.; Rempe, M. Hydrothermal alteration in an exhumed crustal fault zone: Testing geochemical mobility in the Caleta Coloso Fault, Atacama Fault System, Northern Chile. Tectonophysics 2014, 623, 147-168. [CrossRef]

11. Liu, B.; Liu, Y.; Wu, K.; Wang, X.; Pei, Y.; Guo, J. Geochemical characteristics of fault core and damage zones of the Hong-Che Fault Zone of the Junggar Basin (NW China) with implications for the fault sealing process. J. Asian Earth Sci. 2017, 143, 141-155. [CrossRef]

12. Richard, J.; Coulon, M.; Gaviglio, P. Mass transfer controlled by fracturing in micritic carbonate rocks. Tectonophysics 2002, 350, 17-33. [CrossRef]

13. Richard, J. Large-scale mass transfers related to pressure solution creep-faulting interactions in mudstones: Driving processes and impact of lithification degree. Tectonophysics 2014, 612-613, 40-55. [CrossRef] 
14. Fossen, H.; Schultz, R.A.; Shipton, Z.K.; Mair, K. Deformation bands in sandstone: A review. J. Geol. Soc. London. 2007, 164, 755-769. [CrossRef]

15. Dockrill, B.; Shipton, Z.K. Structural controls on leakage from a natural $\mathrm{CO}_{2}$ geologic storage site: Central Utah, U.S.A. J. Struct. Geol. 2010, 32, 1768-1782. [CrossRef]

16. Bauer, J.F.; Meier, S.; Philipp, S.L. Architecture, fracture system, mechanical properties and permeability structure of a fault zone in Lower Triassic sandstone, Upper Rhine Graben. Tectonophysics 2015, 647-648, 132-145. [CrossRef]

17. Frery, E.; Gratier, J.; Ellouz-Zimmerman, N.; Loiselet, C.; Braun, J.; Deschamps, P.; Blamart, D.; Hamelin, B.; Swennen, R. Evolution of fault permeability during episodic fluid circulation: Evidence for the effects of fluid-rock interactions from travertine studies (Utah-USA). Tectonophysics 2015, 651-652, 121-137. [CrossRef]

18. Indrevær, K.; Stunitz, H.; Bergh, S.G. On Palaeozoic-Mesozoic brittle normal faults along the SW Barents Sea margin: Fault processes and implications for basement permeability and margin evolution. J. Geol. Soc. London. 2014, 171, 831-846. [CrossRef]

19. Si, J.; Li, H.; Kuo, L.; Huang, J.; Song, S.; Pei, J.; Wang, H.; Song, L.; Fang, J.; Sheu, H. Carbonaceous Materials in the Longmenshan Fault Belt Zone: 3. Records of Seismic Slip from the Trench and Implications for Faulting Mechanisms. Minerals 2018, 8, 457. [CrossRef]

20. Yielding, G.; Freeman, B.; Needham, D.T. Quantitative Fault Seal Prediction. AAPG Bull. 1997, 81, 897-917.

21. Jones, R.M.; Hillis, R.R. An integrated, quantitative approach to assessing fault-seal risk. AAPG Bull. 2003, 87, 507-524. [CrossRef]

22. Tenthorey, E.; Cox, S.F.; Todd, H.F. Evolution of strength recovery and permeability during fluid-rock reaction in experimental fault zones. Earth Planet. Sc. Lett. 2003, 206, 161-172. [CrossRef]

23. Solum, J.G.; van der Pluijm, B.A.; Peacor, D.R. Neocrystallization, fabrics and age of clay minerals from an exposure of the Moab Fault, Utah. J. Struct. Geol. 2005, 27, 1563-1576. [CrossRef]

24. Sun, Y.; Jiang, S.Y.; Wei, Z.; Lu, X.C. Nano-Coating Texture on the Shear Slip Surface in Rocky Materials. Adv. Mater. Res. 2013, 669, 108-114. [CrossRef]

25. Viti, C.; Collettini, C.; Tesei, T. Pressure solution seams in carbonatic fault rocks: Mineralogy, micro/nanostructures and deformation mechanism. Contrib. Mineral. Petr. 2014, 167, 970. [CrossRef]

26. Frodsham, K.; Gayer, R.A. The impact of tectonic deformation upon coal seams in the South Wales coalfield, UK. Int. J. Coal Geol. 1999, 38, 297-332. [CrossRef]

27. Jiang, B.; Qu, Z.; Wang, G.G.X.; Li, M. Effects of structural deformation on formation of coalbed methane reservoirs in Huaibei coalfield, China. Int. J. Coal Geol. 2010, 82, 175-183. [CrossRef]

28. Ju, Y.; Li, X. New research progress on the ultrastructure of tectonically deformed coals. Prog. Nat. Sci. Mater. 2009, 19, 1455-1466. [CrossRef]

29. Li, W.; Jiang, B.; Moore, T.A.; Wang, G.; Liu, J.; Song, Y. Characterization of the Chemical Structure of Tectonically Deformed Coals. Energ. Fuel. 2017, 31, 6977-6985. [CrossRef]

30. Pan, J.; Zhu, H.; Hou, Q.; Wang, H.; Wang, S. Macromolecular and pore structures of Chinese tectonically deformed coal studied by atomic force microscopy. Fuel 2015, 139, 94-101. [CrossRef]

31. Song, Y.; Jiang, B.; Li, F.; Liu, J. Structure and fractal characteristic of micro- and meso-pores in low, middle-rank tectonic deformed coals by $\mathrm{CO}_{2}$ and $\mathrm{N}_{2}$ adsorption. Micropor. Mesopor. Mat. 2017, 253, 191-202.

32. Liu, Q.; Zhang, K.; Zhou, H.; Cheng, Y.; Zhang, H.; Wang, L. Experimental investigation into the damage-induced permeability and deformation relationship of tectonically deformed coal from Huainan coalfield, China. J. Nat. Gas Sci. Eng. 2018, 60, 202-213. [CrossRef]

33. Zhang, Z.; Cao, S.; Li, Y.; Guo, P.; Yang, H.; Yang, T. Effect of moisture content on methane adsorption- and desorption-induced deformation of tectonically deformed coal. Adsorpt. Sci. Technol. 2018, 36, 1648-1668. [CrossRef]

34. Li, F.; Jiang, B.; Cheng, G.; Song, Y.; Tang, Z. Structural and evolutionary characteristics of pores-microfractures and their influence on coalbed methane exploitation in high-rank brittle tectonically deformed coals of the Yangquan mining area, northeastern Qinshui basin, China. J. Petrol. Sci. Eng. 2019, 174, 1290-1302.

35. Xie, P.; Hower, J.C.; Liu, X. Petrographic characteristics of the brecciated coals from Panxian county, Guizhou, southwestern China. Fuel 2019, 243, 1-9. [CrossRef]

36. Karayiğit, A.İ; Mastalerz, M.; Oskay, R.G.; Buzkan, İ. Bituminous coal seams from underground mines in the Zonguldak Basin (NW Turkey): Insights from mineralogy, coal petrography, Rock-Eval pyrolysis, and meso-and microporosity. Int. J. Coal Geol. 2018, 199, 91-112. [CrossRef] 
37. Cao, D.; Li, X.; Zhang, S. Influence of tectonic stress on coalification: Stress degradation mechanism and stress polycondensation mechanism. Sci. China Ser. D 2007, 50, 43-54. [CrossRef]

38. Hou, Q.; Li, H.; Fan, J.; Ju, Y.; Wang, T.; Li, X.; Wu, Y. Structure and coalbed methane occurrence in tectonically deformed coals. Sci. China Earth Sci. 2012, 55, 1755-1763. [CrossRef]

39. Xu, R.; Li, H.; Hou, Q.; Li, X.; Yu, L. The effect of different deformation mechanisms on the chemical structure of anthracite coals. Sci. China Earth Sci. 2015, 58, 502-509. [CrossRef]

40. Song, Y.; Jiang, B.; Han, Y. Macromolecular response to tectonic deformation in low-rank tectonically deformed coals (TDCs). Fuel 2018, 219, 279-287. [CrossRef]

41. Bustin, R.M. Heating during thrust faulting in the Rocky mountains: Friction or fiction? Tectonophysics 1983, 95, 309-328. [CrossRef]

42. Cao, Y.X.; Mitchell, G.D.; Davis, A.; Wang, D.M. Deformation metamorphism of bituminous and anthracite coals from China. Int. J. Coal Geol. 2000, 43, 227-242. [CrossRef]

43. Cao, Y.X.; Davis, A.; Liu, R.X.; Liu, X.W.; Zhang, Y.G. The influence of tectonic deformation on some geochemical properties of coals-A possible indicator of outburst potential. Int. J. Coal Geol. 2003, 53, 69-79. [CrossRef]

44. Chen, J.; Liu, G.; Jiang, M.; Chou, C.; Li, H.; Wu, B.; Zheng, L.; Jiang, D. Geochemistry of environmentally sensitive trace elements in Permian coals from the Huainan coalfield, Anhui, China. Int. J. Coal Geol. 2011, 88, 41-54. [CrossRef]

45. Saikia, J.; Narzary, B.; Roy, S.; Bordoloi, M.; Saikia, P.; Saikia, B.K. Nanominerals, fullerene aggregates, and hazardous elements in coal and coal combustion-generated aerosols: An environmental and toxicological assessment. Chemosphere 2016, 164, 84-91. [CrossRef] [PubMed]

46. Dai, S.; Finkelman, R.B. Coal as a promising source of critical elements: Progress and future prospects. Int. J. Coal Geol. 2018, 186, 155-164. [CrossRef]

47. Stewart, B.W.; Capo, R.C.; Hedin, B.C.; Hedin, R.S. Rare earth element resources in coal mine drainage and treatment precipitates in the Appalachian Basin, USA. Int. J. Coal Geol. 2017, 169, 28-39. [CrossRef]

48. Dai, S.; Yan, X.; Ward, C.R.; Hower, J.C.; Zhao, L.; Wang, X.; Zhao, L.; Ren, D.; Finkelman, R.B. Valuable elements in Chinese coals: A review. Int. Geol. Rev. 2016, 60, 590-620. [CrossRef]

49. Dai, S.; Ren, D.; Chou, C.; Finkelman, R.B.; Seredin, V.V.; Zhou, Y. Geochemistry of trace elements in Chinese coals: A review of abundances, genetic types, impacts on human health, and industrial utilization. Int. J. Coal Geol. 2012, 94, 3-21. [CrossRef]

50. Dai, S.; Luo, Y.; Seredin, V.V.; Ward, C.R.; Hower, J.C.; Zhao, L.; Liu, S.; Zhao, C.; Tian, H.; Zou, J. Revisiting the late Permian coal from the Huayingshan, Sichuan, southwestern China: Enrichment and occurrence modes of minerals and trace elements. Int. J. Coal Geol. 2014, 122, 110-128. [CrossRef]

51. Bullock, L.; Parnell, J.; Perez, M.; Feldmann, J. Tellurium Enrichment in Jurassic Coal, Brora, Scotland. Minerals 2017, 7, 231. [CrossRef]

52. Yuan, Y.; Tang, S.; Zhang, S. Geochemical and Mineralogical Characteristics of the Middle Jurassic Coals from the Tongjialiang Mine in the Northern Datong Coalfield, Shanxi Province, China. Minerals 2019, 9, 184. [CrossRef]

53. Karayiğit, A.I.; Bircan, C.; Mastalerz, M.; Oskay, R.G.; Querol, X.; Lieberman, N.R.; Türkmen, I. Coal characteristics, elemental composition and modes of occurrence of some elements in the İsaalan coal (Balıkesir, NW Turkey). Int. J. Coal Geol. 2017, 172, 43-59. [CrossRef]

54. Dai, S.; Ji, D.; Ward, C.R.; French, D.; Hower, J.C.; Yan, X.; Wei, Q. Mississippian anthracites in Guangxi Province, southern China: Petrological, mineralogical, and rare earth element evidence for high-temperature solutions. Int. J. Coal Geol. 2018, 197, 84-114. [CrossRef]

55. Chen, J.; Liu, G.; Li, H.; Wu, B. Mineralogical and geochemical responses of coal to igneous intrusion in the Pansan Coal Mine of the Huainan coalfield, Anhui, China. Int. J. Coal Geol. 2014, 124, 11-35. [CrossRef]

56. Dai, S.; Wang, X.; Zhou, Y.; Hower, J.C.; Li, D.; Chen, W.; Zhu, X.; Zou, J. Chemical and mineralogical compositions of silicic, mafic, and alkali tonsteins in the late Permian coals from the Songzao Coalfield, Chongqing, Southwest China. Chem. Geol. 2011, 282, 29-44. [CrossRef]

57. Fowler, P.; Gayer, R.A. The association between tectonic deformation, inorganic composition and coal rank in the bituminous coals from the South Wales coalfield, United Kingdom. Int. J. Coal Geol. 1999, 42, 1-31. [CrossRef] 
58. Dawson, G.K.W.; Golding, S.D.; Esterle, J.S.; Massarotto, P. Occurrence of minerals within fractures and matrix of selected Bowen and Ruhr Basin coals. Int. J. Coal Geol. 2012, 94, 150-166. [CrossRef]

59. Hower, J.C.; Williams, D.A.; Eble, C.F.; Sakulpitakphon, T.; Moecher, D.P. Brecciated and mineralized coals in Union County, Western Kentucky coal field. Int. J. Coal Geol. 2001, 47, 223-234. [CrossRef]

60. Permana, A.K.; Ward, C.R.; Li, Z.; Gurba, L.W. Distribution and origin of minerals in high-rank coals of the South Walker Creek area, Bowen Basin, Australia. Int. J. Coal Geol. 2013, 116-117, 185-207. [CrossRef]

61. Karayiğit, A.I.; Mastalerz, M.; Oskay, R.G.; Gayer, R.A. Coal petrography, mineralogy, elemental compositions and palaeoenvironmental interpretation of Late Carboniferous coal seams in three wells from the Kozlu coalfield (Zonguldak Basin, NW Turkey). Int. J. Coal Geol. 2018, 187, 54-70. [CrossRef]

62. Song, Y.; Jiang, B.; Liu, H.; Li, F.; Shao, P.; Yan, G. Variations in stress-sensitive minerals and elements in the tectonic-deformation Early to Middle Permian coals from the Zhuxianzhuang mine, Anhui Province. J. Geochem. Explor. 2018, 188, 11-23.

63. Ghosh, S.; Rodrigues, S.; Varma, A.K.; Esterle, J.; Patra, S.; Dirghangi, S.S. Petrographic and Raman spectroscopic characterization of coal from Himalayan fold-thrust belts of Sikkim, India. Int. J. Coal Geol. 2018, 196, 246-259. [CrossRef]

64. Liu, X.; Song, D.; He, X.; Nie, B.; Wang, L. Insight into the macromolecular structural differences between hard coal and deformed soft coal. Fuel 2019, 245, 188-197. [CrossRef]

65. Li, Y.; Jiang, B.; Qu, Z. Controls on migration and aggregation for tectonically sensitive elements in tectonically deformed coal: An example from the Haizi mine, Huaibei coalfield, China. Sci. China Earth Sci. 2014, 57, 1180-1191. [CrossRef]

66. Yang, M.; Liu, G.; Sun, R.; Chou, C.; Zheng, L. Characterization of intrusive rocks and REE geochemistry of coals from the Zhuji Coal Mine, Huainan Coalfield, Anhui, China. Int. J. Coal Geol. 2012, 94, 283-295. [CrossRef]

67. Jiang, B.; Li, Y.; Qu, Z.; Li, M. Preliminary study on theory and method of structural geochemistry of gas outburst prediction. J. China Coal Soc. 2015, 40, 1408-1414, (In Chinese with English abstract).

68. Shen, H.Z. Hydrogeological characteristics of the fourth aquifer in Sunan coal mine. Master's Thesis, Anhui University of Science \& Technology, Huainan, China, 2005. (In Chinese with English abstract).

69. Li, M. Structure evolution and deformation mechanism of tectonically deformed coal. Ph.D. Thesis, China University of Mining and Technology, Xuzhou, China, 2013. (In Chinese with English abstract).

70. China State Bureau of Technical Supervision. Sampling of Coal in Seam (GB482-1995); Standards Press of China: Beijing, China, 1995. (In Chinese)

71. Liu, J.; Jiang, B.; Li, M.; Qu, Z.; Wang, L.; Li, L. Structural control on pore-fracture characteristics of coals from Xinjing coal mine, northeastern Qinshui basin, China. Arab. J. Geosci. 2015, 8, 4421-4431. [CrossRef]

72. Ward, C.R. Analysis and significance of mineral matter in coal seams. Int. J. Coal Geol. 2002, 50, 135-168. [CrossRef]

73. Buatier, M.D.; Trave, A.; Labaume, P.; Potdevin, J.L. Dickite related to fluid-sediment interaction and deformation in Pyrenean thrust fault zones. Eur. J. Mineral. 1997, 9, 875-888. [CrossRef]

74. Dai, S.; Graham, I.T.; Ward, C.R. A review of anomalous rare earth elements and yttrium in coal. Int. J. Coal Geol. 2016, 159, 82-95. [CrossRef]

75. Seredin, V.V.; Dai, S. Coal deposits as potential alternative sources for lanthanides and yttrium. Int. J. Coal Geol. 2012, 94, 67-93. [CrossRef]

76. Taylor, S.R.; McLennan, S.M. The Continental Crust: Its Composition and Evolution; Blackwell Scientific Publication: Carlton, Australia, 1985; Volume 94.

77. Yan, X.; Dai, S.; Graham, I.T.; He, X.; Shan, K.; Liu, X. Determination of Eu concentrations in coal, fly ash and sedimentary rocks using a cation exchange resin and inductively coupled plasma mass spectrometry (ICP-MS). Int. J. Coal Geol. 2018, 191, 152-156. [CrossRef]

78. Eskenazy, G.M. Aspects of the geochemistry of rare earth elements in coal: An experimental approach. Int. J. Coal Geol. 1999, 38, 285-295. [CrossRef]

79. Zheng, L.; Liu, G.; Chou, C.; Qi, C.; Zhang, Y. Geochemistry of rare earth elements in Permian coals from the Huaibei Coalfield, China. J. Asian Earth Sci. 2007, 31, 167-176. [CrossRef]

80. Zheng, L.; Liu, G.; Wang, L.; Chou, C. Composition and quality of coals in the Huaibei Coalfield, Anhui, China. J. Geochem. Explor. 2008, 97, 59-68. [CrossRef] 
81. Dai, S.; Xie, P.; Jia, S.; Ward, C.R.; Hower, J.C.; Yan, X.; French, D. Enrichment of U-Re-V-Cr-Se and rare earth elements in the Late Permian coals of the Moxinpo Coalfield, Chongqing, China: Genetic implications from geochemical and mineralogical data. Ore Geol. Rev. 2017, 80,1-17. [CrossRef]

82. Dai, S.; Seredin, V.V.; Ward, C.R.; Hower, J.C.; Xing, Y.; Zhang, W.; Song, W.; Wang, P. Enrichment of U-Se-Mo-Re-V in coals preserved within marine carbonate successions: Geochemical and mineralogical data from the Late Permian Guiding Coalfield, Guizhou, China. Miner. Depos. 2015, 50, 159-186. [CrossRef]

83. Zhang, J.; Ren, D.; Zheng, C.; Zeng, R.; Chou, C.; Liu, J. Trace element abundances in major minerals of Late Permian coals from southwestern Guizhou province, China. Int. J. Coal Geol. 2002, 53, 55-64. [CrossRef]

84. Dai, S.; Jiang, Y.; Ward, C.R.; Gu, L.; Seredin, V.V.; Liu, H.; Zhou, D.; Wang, X.; Sun, Y.; Zou, J.; et al. Mineralogical and geochemical compositions of the coal in the Guanbanwusu Mine, Inner Mongolia, China: Further evidence for the existence of an $\mathrm{Al}$ (Ga and REE) ore deposit in the Jungar Coalfield. Int. J. Coal Geol. 2012, 98, 10-40. [CrossRef]

85. Tian, C.; Zhang, J.; Zhao, Y.; Gupta, R. Understanding of mineralogy and residence of trace elements in coals via a novel method combining low temperature ashing and float-sink technique. Int. J. Coal Geol. 2014, 131, 162-171. [CrossRef]

86. Finkelman, R.B.; Palmer, C.A.; Wang, P. Quantification of the modes of occurrence of 42 elements in coal. Int. J. Coal Geol. 2018, 185, 138-160. [CrossRef]

87. Dai, S.; Li, T.; Seredin, V.V.; Ward, C.R.; Hower, J.C.; Zhou, Y.; Zhang, M.; Song, W.; Song, X.; Zhao, C. Origin of minerals and elements in the Late Permian coals, tonsteins, and host rocks of the Xinde Mine, Xuanwei, eastern Yunnan, China. Int. J. Coal Geol. 2014, 121, 53-78. [CrossRef]

88. Dai, S.; Zhang, W.; Ward, C.R.; Seredin, V.V.; Hower, J.C.; Li, X.; Song, W.; Wang, X.; Kang, H.; Zheng, L.; et al. Mineralogical and geochemical anomalies of late Permian coals from the Fusui Coalfield, Guangxi Province, southern China: Influences of terrigenous materials and hydrothermal fluids. Int. J. Coal Geol. 2013, 105, 60-84. [CrossRef]

89. Kolker, A.; Chou, C. Cleat-Filling Calcite in Illinois Basin Coals: Trace-Element Evidence for Meteoric Fluid Migration in a Coal Basin. J. Geol. 1994, 102, 111-116. [CrossRef]

90. Bouška, V.; Pesek, J.; Sykorova, I. Probable Modes of Occurrence of Chemical Elements in Coal. Acta Mont. Ser. B. 2000, 117, 53-90.

91. Dai, S.; Li, D.; Ren, D.; Tang, Y.; Shao, L.; Song, H. Geochemistry of the late Permian No. 30 coal seam, Zhijin Coalfield of Southwest China: Influence of a siliceous low-temperature hydrothermal fluid. Appl. Geochem. 2004, 19, 1315-1330. [CrossRef]

92. Ju, Y.; Luxbacher, K.; Li, X.; Wang, G.; Yan, Z.; Wei, M.; Yu, L. Micro-structural evolution and their effects on physical properties in different types of tectonically deformed coals. Int. J. Coal Sci. Technol. 2014, 1, 364-375. [CrossRef]

93. Li, B.; Zhuang, X.; Querol, X.; Moreno, N.; Córdoba, P.; Li, J.; Zhou, J.; Ma, X.; Liu, S.; Shangguan, Y. The mode of occurrence and origin of minerals in the Early Permian high-rank coals of the Jimunai depression, Xinjiang Uygur Autonomous Region, NW China. Int. J. Coal Geol. 2019, 205, 58-74. [CrossRef]

94. Li, M.; Jiang, B.; Lin, S.; Lan, F.; Wang, J. Structural Controls on Coalbed Methane Reservoirs in Faer Coal Mine, Southwest China. J. Earth Sci. China 2013, 24, 437-448. [CrossRef]

95. Niu, Q.; Pan, J.; Cao, L.; Ji, Z.; Wang, H.; Wang, K.; Wang, Z. The evolution and formation mechanisms of closed pores in coal. Fuel 2017, 200, 555-563. [CrossRef]

96. Chen, Y.; Qin, Y.; Wei, C.; Huang, L.; Shi, Q.; Wu, C.; Zhang, X. Porosity changes in progressively pulverized anthracite subsamples: Implications for the study of closed pore distribution in coals. Fuel 2018, 225, 612-622. [CrossRef]

97. Karacan, C.O.; Okandan, E. Fracture/cleat analysis of coals from Zonguldak Basin (northwestern Turkey) relative to the potential of coalbed methane production. Int. J. Coal Geol. 2000, 44, 109-125. [CrossRef]

98. Renard, F.; Gratier, J.; Jamtveit, B. Kinetics of crack-sealing, intergranular pressure solution, and compaction around active faults. J. Struct. Geol. 2000, 22, 1395-1407. [CrossRef]

99. Ju, Y.; Sun, Y.; Wan, Q.; Lu, S.; He, H.; Wu, J.; Zhang, W.; Wang, G.; Huang, C. Nanogeology: A Revolutionary Challenge in Geosciences. Bull. Mineral. Petrol. Geochem. 2016, 35, 1-20.

100. Vannucchi, P.; Maltman, A.; Bettelli, G.; Clennell, B. On the nature of scaly fabric and scaly clay. J. Struct. Geol. 2003, 25, 673-688. [CrossRef] 
101. Guo, D.; Han, D.; Chen, Y.; Liu, F. Quantitative study of surface components of outburst coal with XPS method. Coal Eng. 1996, 1, 2-4, (In Chinese with English abstract).

102. Kristof, J.; Frost, R.L.; Kloprogge, J.T.; Horvath, E.; Mako, E. Detection of four different OH-groups in ground kaolinite with controlled-rate thermal analysis. J. Therm. Anal. Calorim. 2002, 69, 77-83. [CrossRef]

103. Strydom, C.A.; Bunt, J.R.; Schobert, H.H.; Raghoo, M. Changes to the organic functional groups of an inertinite rich medium rank bituminous coal during acid treatment processes. Fuel Process. Technol. 2011, 92, 764-770. [CrossRef]

104. Serratosa, J.M.; Hidalgo, J.M.; Vinas, J.M. Orientation of OH Bonds in Kaolinite. Nature 1962, 195, $486-487$. [CrossRef]

105. Ledoux, R.L.; White, J.L. Infrared Study of the OH Groups in Expanded Kaolinite. Science 1964, 143, $244-246$. [CrossRef] [PubMed]

106. Brindley, W.G.; Kao, C.C.; Harrison, J.L. Relation between Structural Disorder and Other Characteristics of Kaolinites and Dickites. Clay Clay Miner. 1986, 34, 239-249. [CrossRef]

107. Michalkova, A.; Szymczak, J.J.; Leszczynski, J. Adsorption of 2,4-Dinitrotoluene on Dickite: The Role of H-Bonding. Struct. Chem. 2005, 16, 325-337. [CrossRef]

108. Welch, M.D.; Crichton, W.A. Pressure-induced transformations in kaolinite. Am. Mineral. 2010, 95, 651-654. [CrossRef]

109. Ogasawara, M. Geochemistry of Rare-Earth Elements. Min. Geol. 2009, 39, 166-176.

110. Seredin, V.V. Rare earth element-bearing coals from the Russian Far East deposits. Int. J. Coal Geol. 1996, 30, 101-129. [CrossRef]

111. Bradbury, M.H.; Baeyens, B. Sorption of Eu on Na- and Ca-montmorillonites: Experimental investigations and modelling with cation exchange and surface complexation. Geochim. Cosmochim. Acta 2002, 66, 2325-2334. [CrossRef]

112. Moldoveanu, G.A.; Papangelakis, V.G. Recovery of rare earth elements adsorbed on clay minerals: I. Desorption mechanism. Hydrometallurgy 2012, 117-118, 71-78. [CrossRef]

113. Moldoveanu, G.A.; Papangelakis, V.G. Recovery of rare earth elements adsorbed on clay minerals: II. Leaching with ammonium sulfate. Hydrometallurgy 2013, 131-132, 158-166. [CrossRef]

114. Sen Gupta, S.; Bhattacharyya, K.G. Kinetics of adsorption of metal ions on inorganic materials: A review. Adv. Colloid Interfac. 2011, 162, 39-58. [CrossRef]

115. Tertre, E.; Berger, G.; Simoni, E.; Castet, S.; Giffaut, E.; Loubet, M.; Catalette, H. Europium retention onto clay minerals from 25 to $150{ }^{\circ} \mathrm{C}$ : Experimental measurements, spectroscopic features and sorption modelling. Geochim. Cosmochim. Acta 2006, 70, 4563-4578. [CrossRef]

116. Geckeis, H.; Lützenkirchen, J.; Polly, R.; Rabung, T.; Schmidt, M. Mineral-Water Interface Reactions of Actinides. Chem. Rev. 2012, 113, 1016-1062. [CrossRef] [PubMed]

117. Martin, L.A.; Wissocq, A.; Benedetti, M.F.; Latrille, C. Thallium (Tl) sorption onto illite and smectite: Implications for Tl mobility in the environment. Geochim. Cosmochim. Acta 2018, 230, 1-16. [CrossRef]

118. Coppin, F.; Berger, G.; Bauer, A.; Castet, S.; Loubet, M. Sorption of lanthanides on smectite and kaolinite. Chem. Geol. 2002, 182, 57-68. [CrossRef]

119. Schleicher, A.M.; van der Pluijm, B.A.; Warr, L.N. Nanocoatings of clay and creep of the San Andreas fault at Parkfield, California. Geology 2010, 38, 667-670. [CrossRef]

120. Sun, Y.; Shu, L.; Lu, X.; Liu, H.; Zhang, X.; Kosaka, K.; Lin, A. A comparative study of natural and experimental nano-sized grinding grain textures in rocks. Chin. Sci. Bull. 2008, 53, 1217-1221. [CrossRef]

121. Hochella, M.F.; Lower, S.K.; Maurice, P.A.; Penn, R.L.; Sahai, N.; Sparks, D.L.; Twining, B.S. Nanominerals, Mineral Nanoparticles, and Earth Systems. Science 2008, 319, 1631-1635. [CrossRef]

122. Silva, L.F.O.; Jasper, A.; Andrade, M.L.; Sampaio, C.H.; Dai, S.; Li, X.; Li, T.; Chen, W.; Wang, X.; Liu, H.; et al. Applied investigation on the interaction of hazardous elements binding on ultrafine and nanoparticles in Chinese anthracite-derived fly ash. Sci. Total Environ. 2012, 419, 250-264. [CrossRef]

123. Chen, T.; Xie, Q.; Liu, H.; Xie, J.; Zhou, Y. Nano-minerals and nano-mineral resources. Earth Sci. 2018, 43, 1439-1449, (In Chinese with English abstract).

124. Mastalerz, M. Modes of occurrence of trace elements in coal. Int. J. Coal Geol. 2001, 46, 66. [CrossRef]

125. Chatterjee, P.K. Coal mining disasters in New South Wales and Queensland between 1920-1979-A technical appraisal: Proc Australas Inst Min Metall, N281, March 1982, P37-43. Int. J. Rock Mech. Min. Sci. Geomech. Abstr. 1982, 19, 136. [CrossRef] 
126. Finkelman, R.B. Trace elements in coal. Biol. Trace Elem. Res. 1999, 67, 197-204. [CrossRef] [PubMed]

127. Liu, J.; Yang, Z.; Yan, X.; Ji, D.; Yang, Y.; Hu, L. Modes of occurrence of highly-elevated trace elements in superhigh-organic-sulfur coals. Fuel 2015, 156, 190-197. [CrossRef]

128. Mizera, J.; Mizerová, G.; Machovič, V.; Borecká, L. Sorption of cesium, cobalt and europium on low-rank coal and chitosan. Water Res. 2007, 41, 620-626. [CrossRef] [PubMed]

129. Wang, Z.; Bai, Z.; Li, W.; Bai, J.; Guo, Z.; Chen, H. Effects of ion-exchanged calcium, barium and magnesium on cross-linking reactions during direct liquefaction of oxidized lignite. Fuel Process. Technol. 2012, 94, 34-39. [CrossRef]

130. O'Hara, K. Paleo-stress estimates on ancient seismogenic faults based on frictional heating of coal. Geophys. Res. Lett. 2004, 31. [CrossRef]

131. Kitamura, M.; Mukoyoshi, H.; Fulton, P.M.; Hirose, T. Coal maturation by frictional heat during rapid fault slip. Geophys. Res. Lett. 2012, 39. [CrossRef]

132. Liu, H.; Jiang, B.; Liu, J.; Song, Y. The evolutionary characteristics and mechanisms of coal chemical structure in micro deformed domains under sub-high temperatures and high pressures. Fuel 2018, 222, 258-268. [CrossRef]

(C) 2019 by the authors. Licensee MDPI, Basel, Switzerland. This article is an open access article distributed under the terms and conditions of the Creative Commons Attribution (CC BY) license (http://creativecommons.org/licenses/by/4.0/). 